\title{
ARCHIBALD COX AND THE \\ DIVERSITY JUSTIFICATION FOR AFFIRMATIVE ACTION
}

David B. Oppenheimer *

INTRODUCTION 160

I. REDISCOVERING THE ARCHIBALD COX AMICUS CURIAE BRIEF IN DEFUNIS V. ODEGAARD 169

II. WHAT WERE THE SOURCES FOR COX'S DESCRIPTION OF HARVARD'S AFFIRMATIVE ACTION PROGRAM?

III. THE ORIGINS OF THE DIVERSITY JUSTIFICATION FOR AFFIRMATIVE

ACTION

IV. COX, HARVARD, AND AFFIRMATIVE ACTION AFTER DEFUNIS.

CONCLUSION 203

* Clinical Professor of Law, Berkeley Law. I am grateful to my extraordinary Berkeley Law research assistants Rachel Foodman, Lizzie Fulton, Nina Gupta, Daniel Myerson, Candice Shikai and Jasleen Kaur Singh, to my Berkeley undergraduate research assistants Rishi Ahuja, Naomi Adaeze Uwaka, and Julian Zhu, to Berkeley Law librarians Doug Avila, I-Wei Wang, and Marci Hoffman, and to Jim Bierman, Andrew Brandt, Jim Brosnahan, Bob Comfort, Fred Glimp, Marcy Kates, Ian Haney-Lopez, David Lieberman, Jack McNulty and Charles Puttkammer. They deserve most of the credit for this work, but any errors or omissions are mine alone. 


\section{ARCHIBALD COX AND THE DIVERSITY JUSTIFICATION FOR AFFIRMATIVE ACTION}

David B. Oppenheimer

Discussions of the value of racial, ethnic and gender diversity are so commonplace today that anyone born after 1990 could be excused for thinking that these forms of identity diversity have long been associated with social policy, including affirmative action in employment and university admissions. But prior to 1978 there was virtually no discussion of the value of diversity; the justifications for affirmative action and other civil rights remedies focused on promoting equality and combating discrimination. This article reveals the origins of the diversity justification for affirmative action - the only defense that survives judicial scrutiny today.

The conventional wisdom is that Justice Lewis Powell developed the diversity justification by relying on an amicus curiae brief filed in the Bakke case in 1978. Yet it was actually four years earlier that Justice Powell first encountered the diversity justification, in an amicus brief in the DeFunis case, which was subsequently dismissed as moot, and has thus been largely ignored. The author of that brief was the great American lawyer and legal scholar Archibald Cox, who was only available because he had been unexpectedly fired by President Nixon from his role as the Watergate Special Prosecutor in the "Saturday Night Massacre." When he returned to Cambridge he agreed to write a brief defending affirmative action by describing how and why race was utilized at Harvard to increase student diversity. That this is an argument that seems commonplace, even obvious, today is a testament to the persuasiveness of the Cox brief. In 1974 it was unique, and it caught Justice Powell's eye as a better way to justify affirmative action than the other traditional arguments.

In developing his description and justification for affirmative action at Harvard, Cox relied on a history of embracing diversity that began in the 1860 's under the leadership of Harvard's great transformative President, Charles W. Eliot. I here describe how Eliot's commitment to diversity, including point-of-view and experiential diversity, as well as racial, ethnic and religious diversity, helped make Harvard the model of a great university. Eliot's passion for diversity resonated at Harvard in the post-World War II period, as the university abandoned its despicable Jewish quota, which Eliot had opposed, and began reaching out and recruiting students from underrepresented groups. Cox relied on the architects of those post-war policies in drafting his description of the Harvard plan 
in the DeFunis brief. When the Cox diversity argument appeared again four years later in the Bakke case, under different authorship, Powell recognized it from four years earlier, and again embraced it. His opinion in Bakke quotes extensively from Cox's description of Harvard's diversity-based affirmative action program, holding it up as a model to emulate. Justice Powell's description, taken from the Cox brief, has become the blueprint that nearly all selective colleges now follow, and was recently reaffirmed by the Court in the Fisher case. But what happened to Cox's brief that paved the way, first describing the diversity justification for affirmative action as we know it today? It mysteriously disappeared.

\section{INTRODUCTION}

A MICUS curiae briefs play an unusual role in American law. Thousands of these briefs are filed every year in the U.S. Supreme Court. In most cases, they are inconsequential. In a few, they affect the outcome of the case. In very rare instances, they change our society. This is the story of one such brief, written by one of the greatest lawyers of the twentieth century, Archibald Cox. ${ }^{1}$ The brief not only affected the outcome of a case, but also changed how we think about race and racism, and other forms of identity. It paved the way for the only remaining justification of affirmative action policies that meets the requirements of the Equal Protection Clause of the Constitution. One might expect such a brief to be widely read and celebrated, but it is virtually unknown and has mysteriously disappeared from the databases that collect and preserve Supreme Court records.

It is fitting that Cox's history-changing brief addressed affirmative action because amicus briefs have been unusually important in the area of affirmative action in higher education. The Supreme Court has addressed the legality of affirmative action in higher education five times between 1978 and 2016: in the twice-reviewed University of Texas undergraduate admissions case, the two University of Michigan cases (undergraduate and law school), and in the University of California Davis medical school case. ${ }^{2}$ In these five cases, which produced 25 separate

${ }^{1}$ See Brief for the President and Fellows of Harvard College as Amicus Curiae Supporting Respondents, DeFunis v. Odegaard, 416 U.S. 312 (1974) (No. 73-235) [hereinafter Cox Brief]. As explained below, the brief is difficult to access, and has thus been reprinted at the end of this article, at page 205 .

${ }^{2}$ Fisher v. University of Texas (Fisher I) 133 S. Ct. 2411 (2013) (separate opinions by Justices Kennedy, Scalia, Thomas and Ginsburg); Fisher v. University of Texas (Fisher II), 136 S. Ct. 2198 (2016) (separate opinions by Justices Kennedy, Thomas and Alito); Gratz v. Bollinger, 539 U.S. 244 (2003) (separate opinions by Justices Rehnquist, O'Connor, Thomas, Breyer, Souter and Ginsburg); Grutter v. Bollinger, 539 U.S. 306 (2003) (separate opinions by Justices O'Connor, Ginsburg, Scalia, Thomas, Rehnquist and Kennedy); and Regents of 
opinions, over 350 amicus briefs were filed. In several of the most influential opinions, the Justices relied substantially on arguments made in amicus briefs.

It was in the first of these cases, Regents of the University of California v. Bakke $e^{3}$ in 1978, that Justice Powell articulated and embraced the diversity justification for affirmative action. His ground-breaking endorsement of diversity as a legal justification for race-conscious decision-making in college admissions remains the law today, ${ }^{4}$ and his description of Harvard College's admissions program has become a blueprint for the admissions process of nearly every selective college and university in the United States. ${ }^{5}$ Other potential justifications, including the importance of reversing hundreds of years of discrimination, the continuing social problem of racial disadvantage and inequality, the inadequacy of standardized tests, the value of restorative justice, the right to reparations, the importance of providing trained professionals in minority neighborhoods, or the need to address implicit bias, have fallen away. Few, if any, schools continue to justify affirmative action on these grounds.

How important was Justice Powell's opinion in Bakke? When he stepped down in 1987, after serving for 15 years on the Court, he was asked which was his most important opinion. Without hesitation, he replied, the Bakke opinion, and specifically mentioned that 63 amicus briefs were submitted in the case. ${ }^{6}$ As we will see, it was not one of those 63 amicus briefs, but a different brief from an earlier case, that he primarily relied upon in his opinion.

In his opinion in Bakke, Justice Powell described and relied on Harvard College's admissions program, as described in and appended to an amicus brief filed by four elite private universities (Columbia, Harvard, Stanford and Penn). Justice Powell was so impressed by the Harvard policy he attached the appendix from the brief, in which the policy was described, as an appendix to his opinion. Thus, the amicus brief, and the appendix describing the Harvard program, has taken on iconic status; the brief is recognized as among the most important examples of the power

the University of California v. Bakke, 438 U.S. 265 (1978) (separate opinions by Justices Powell, Brennan, White, Marshall, Blackmun, and Stevens).

${ }^{3}$ Bakke, 438 U.S..

${ }^{4}$ E.g., Fisher II, 136 S. Ct. 2198.

${ }^{5}$ See Bernard Schwartz, Behind BaKke: AfFirmative ACtion AND tHE SUPREME COURT 153-55 (1988) (describing how the Powell opinion in Bakke has become a model for virtually all universities); Grutter v. Bollinger, 539 U.S. 306, 323 (2003) ("Justice Powell's opinion announcing the judgment of the Court has served as the touchstone for constitutional analysis of race-conscious admissions policies.").

${ }^{6}$ SCHWARTZ, supra note 5, at 1 (citing Linda Greenhouse, Powell: Moderation Amid Divisions, N.Y. TIMES, June 27, 1987). 
of amicus briefs to shape the law, and the appendix is the blueprint for nearly all affirmative action admissions programs. ${ }^{7}$

This article reveals that Justice Powell actually first encountered and considered the diversity justification for affirmative action four years before the Bakke decision in DeFunis v. Odegaard, a case now largely forgotten because it was dismissed as moot. He did so based on another amicus brief, filed by Harvard University, describing the Harvard College diversity admissions program in identical terms to the brief filed four years later in the Bakke case. The earlier brief was the unacknowledged source of the description of Harvard's policy that Justice Powell attached to his Bakke opinion as an appendix. It was that earlier brief which paved the way for the judicial embrace of diversity as a justification for race-conscious college admissions. But don't look for it on Westlaw or LexisNexis; it has mysteriously disappeared. ${ }^{8}$ At least at the time of this article's publication, the brief is not included in the Court's record in any of the leading electronic libraries of American law. I have thus proposed, and the editors of this journal have agreed, to re-publish it following this article.

Justice Powell explained in his Bakke opinion that colleges and universities have a right to academic freedom protected by the First Amendment, which includes a right to select their students. ${ }^{9}$ If a university sees value in racial/ethnic diversity in order to broaden the experiences brought by its students to the educational enterprise, the courts should not interfere. But using racial quotas or making race decisive brings the schools' First Amendment interests into conflict with the applicants' Fourteenth Amendment rights. Thus, the method used by U.C. Davis - a separate admissions track for a certain number of places - was impermissible. ${ }^{10}$ In contrast, considering diversity in the way that Harvard College considered diversity was not only permissible, but laudatory. Here, following precisely the arguments made in Cox's DeFunis brief, which were summarized in the Bakke opinion and attached as an appendix, Justice Powell described how Harvard's admission plan

${ }^{7}$ See, e.g., SCHWARTZ, supra note 5, at 153-55.

${ }^{8}$ Copies of the brief are not even available from the U.S. Supreme Court Clerk's Office, though it is available from the Library of Congress and is occasionally described in contemporary and historical accounts. See, e.g., Bruce Kuehne, Cox Writes Amicus Brief in Law Admissions Case, 58 HARV. L. ReCORD Feb. 8, 1974 at 1, 6, 11; Jerome KARABEL, THE CHOSEn: THE Hidden History OF ADMISSION AND EXCLUSION AT HARVARD, YALE, AND PRINCETON 488-89 (2005) (describing the brief and identifying Cox as the author); Charles Ogletree, In Memoriam: Archibald Cox, 118 HARV. L. REV. 14, 14-15 (2004) (same).

${ }^{9}$ Regents of the University of California v. Bakke, 438 U.S. 265, 311-14 (1978).

${ }^{10}$ Id. at $314-16$. 
looked to racial/ethnic diversity to justify considering race in making admissions decisions:

In recent years, Harvard College has expanded the concept of diversity to include students from disadvantaged economic, racial and ethnic groups. . . In practice, this new definition of diversity has meant that race has been a factor in some admission decisions. When the Committee on Admissions reviews the large middle group of applicants who are "admissible" and deemed capable of doing good work in their courses, the race of an applicant may tip the balance in his favor just as geographic origin or a life spent on a farm may tip the balance in other candidates' cases. A farm boy from Idaho can bring something to Harvard College that a Bostonian cannot offer. Similarly, a black student can usually bring something that a white person cannot offer. ...

In such an admissions program, race or ethnic background may be deemed a "plus" in a particular applicant's file, yet it does not insulate the individual from comparison with all other candidates for the available seats... The file of a particular black applicant may be examined for his potential contribution to diversity without the factor of race being decisive when compared, for example, with that of an applicant identified as an Italian-American if the latter is thought to exhibit qualities more likely to promote beneficial educational pluralism. Such qualities could include exceptional personal talents, unique work or service experience, leadership potential, maturity, demonstrated compassion, a history of overcoming disadvantage, ability to communicate with the poor, or other qualifications deemed important. In short, an admissions program operated in this way is flexible enough to consider all pertinent elements of diversity in light of the particular qualifications of each applicant, and to place them on the same footing for consideration, although not necessarily according them the same weight. ${ }^{11}$

Just one other brief in the DeFunis case raises diversity as a justification for affirmative action. Among the most important of the amicus briefs in support of the University of Washington, the Association of American Law Schools (AALS) principally argued that the use of race was permissible because of the state's interest in opening access to the

\footnotetext{
${ }^{11}$ Id. at $316-18$.
} 
bar to minority groups, though it too briefly made a diversity argument. ${ }^{12}$ The Council on Legal Education (CLEO) argued that the use of race was necessary to prevent racial isolation and to address the critical national problem of the underrepresentation of minority groups in the bar. ${ }^{13}$ The American Bar Association (ABA) argued that the use of race was necessary to address the unequal job opportunities for black lawyers. ${ }^{14}$ The Law School Admission Council (LSAC) argued that the use of race was necessary to address the public need for more minority lawyers, and to recognize that minority students with lower numerical qualifications were nonetheless well qualified for law school and that their lower scores were often the result of historical discrimination. ${ }^{15}$ A group of over fifty law school deans argued that the use of race was necessary to overcome past and present discrimination. ${ }^{16}$ A group of civil rights organizations led by the Mexican American Legal Defense and Education Fund, the Puerto Rican Legal Defense and Education Fund, and the American Civil Liberties Union argued that the use of race was necessary to address pervasive and historic discrimination and deprivation. ${ }^{17}$

In the 2016 Fisher $v$. University of Texas (Fisher II) case, the Supreme Court reaffirmed the Powell opinion in Bakke, drawing on the arguments originally set forth in Cox's DeFunis brief. ${ }^{18}$ The Court upheld the ability of universities to use race as a factor in admissions decisions to achieve diversity of its student body, as long as it does not seek to enroll a specific number of minority students. Cox's brief paved the way for race-conscious admissions to survive judicial scrutiny. Today, college admissions programs may be narrowly tailored to achieve diversity, including racial diversity.

${ }^{12}$ Brief for the Association of American Law Schools as Amicus Curiae Supporting Respondents, DeFunis v. Odegaard, 416 U.S. 312 (1974), reprinted in DeFunis Versus OdEgAARD AND THE UNIVERSITY OF WASHINGTON 613 (Ann Fagan Ginger ed., 1974) [hereinafter DEFunIS VERSUS OdEGAARD] (collecting all amicus briefs). See infra note 91.

${ }^{13}$ Brief for the Council on Legal Education Opportunity as Amicus Curiae Supporting Respondents, reprinted in DEFUNIS VERSUS ODEGAARD, supra note 12 , at 635 .

${ }^{14}$ Brief for the American Bar Association as Amicus Curiae Supporting Respondents, DeFunis v. Odegaard, 416 U.S. 312 (1974), reprinted in DEFUNIS VERSUS ODEGAARD, supra note 12, at 665 .

${ }^{15}$ Brief for Law School Admission Council as Amicus Curiae Supporting Respondents, DeFunis v. Odegaard, 416 U.S. 312 (1974), reprinted in DEFUNIS VERSUS ODEGAARD, supra note 12, at 695 .

${ }^{16}$ Brief for a Group of Law School Deans as Amici Curiae Supporting Respondents, DeFunis v. Odegaard, 416 U.S. 312 (1974), reprinted in DEFUNIS VERSUS ODEGAARD, supra note 12, at 725 .

${ }^{17}$ Brief for The Mexican American Legal Defense and Educational Fund, et al. as Amici Curiae Supporting Respondents, DeFunis v. Odegaard, 416 U.S. 312 (1974), in DEFUNIS VERSUS ODEGAARD, supra note 12, at 907.

${ }^{18}$ Fisher v. University of Texas (Fisher II), 136 S. Ct. 2198 (2016). 
Who was Archibald Cox, the lead author of the Harvard brief in the DeFunis case? Cox was widely recognized as one of the great lawyers of his time when he wrote the Harvard brief. He had served as the Solicitor General of the United States, as a leading labor arbitrator, as the Associate Solicitor of Labor, and as a distinguished professor of labor law and constitutional law at Harvard Law School. But he was available on short notice to write this critical brief because his position as the Special Watergate Prosecutor, investigating whether crimes were committed in the 1972 Watergate scandal, had ended abruptly. On October 20, 1973, in what became known as the "Saturday Night Massacre," President Nixon ordered Attorney General Eliot Richardson and Deputy Attorney General William Ruckelshaus to fire Cox. They refused, and instead resigned. Nixon then ordered Solicitor General Robert Bork to fire Cox, which he did (this helped lead to President Nixon's August 9, 1974 resignation on the verge of impeachment, and to the Senate's 1987 rejection of Bork's appointment to the Supreme Court). Cox returned to Cambridge, where his old friend Derek Bok, then President of Harvard University, asked him to use his now-free time to join three other Harvard lawyers to draft an amicus brief in a case then pending in the Supreme Court. ${ }^{19}$ The case was DeFunis v. Odegaard, a challenge to the use of affirmative action at the University of Washington School of Law. Cox became the principal author.

To encounter the brief today is startling. It fully sets forth, in strikingly familiar language, the diversity justification for affirmative action. It is familiar because the text of the appendix to the Bakke brief submitted four years later, which described the role of diversity in Harvard's admissions policies, was simply lifted verbatim from Cox's brief. When Justice Powell took the appendix to the brief and made it an appendix to his Bakke opinion, he was elevating Cox's own description of diversitybased affirmative action at Harvard to a blueprint for other selective colleges to follow.

Cox's amicus brief for DeFunis contains elements that are critical to understanding affirmative action today. The brief describes how scholarly achievement should not serve as the sole criteria in admissions. It expanded the concept of diversity, moving from an understanding of diversity based on geographic background or hobby, to racial and ethnic diversity. It explained that to achieve any meaningful diversity, a school must seek to enroll more than a small number of individuals from any racial or ethnic group. Lastly, Cox discussed how race should be used as a consideration in admissions decisions, without adhering to strict numerical quotas.

${ }^{19}$ E-mail from Derek Bok, President, Harvard University, to David Oppenheimer, Professor of Law, UC Berkeley Law Sch. (May 13, 2013, 10:39 PST) (on file with author) ("I'm hoping you can help me with a research project on the diversity justification for affirmative action"). 
Here is the language from the brief in which Cox describes the Harvard admissions policy. In comparing it to the language of the Bakke appendix, there is only one change: in the two places where Cox uses the term "25 years," the Bakke amicus brief appendix (and hence the Bakke opinion appendix) substitutes "30 years."

For the past 25 years Harvard College has received each year applications for admission that greatly exceed the number of places in the freshman class. The number of applicants who are deemed to be not "qualified" is comparatively small. The vast majority of applicants demonstrate through test scores, high school records and teachers' recommendations that they have the academic ability to do adequate work at Harvard, and perhaps to do it with distinction. Faced with the dilemma of choosing among a large number of "qualified" candidates, the Committee on Admissions could use the single criterion of scholarly excellence and attempt to determine who among the candidates were likely to perform best academically. But for the past 25 years the Committee on Admissions has never adopted this approach. The belief has been that if scholarly excellence were the sole or even predominant criterion, Harvard College would lose a great deal of its vitality and intellectual excellence and that the quality of the educational experience offered to all students would suffer. Final Report of W. J. Bender, Chairman of the Admission and Scholarship Committee and Dean of Admissions and Financial Aid, pp. 20 et seg. (Cambridge, 1960). Consequently, after selecting those students whose intellectual potential will seem extraordinary to the faculty -- perhaps 150 or so out of an entering class of over 1,100 -- the Committee seeks variety in making its choices. This has seemed important. . . in part because it adds a critical ingredient to the effectiveness of the educational experience [in Harvard College] . . The effectiveness of our students' educational experience has seemed to the Committee to be affected as importantly by a wide variety of interests, talents, backgrounds and career goals as it is by a fine faculty and our libraries, laboratories and housing arrangements. (Dean of Admissions Fred L. Glimp, Final Report to the Faculty of Arts and Sciences, 65 Official Register of Harvard University No. 25, 93,104-105 (1968) (emphasis supplied).

The belief that diversity adds an essential ingredient to the educational process has long been a tenet of Harvard College admissions. Fifteen or twenty years ago, how- 
ever, diversity meant students from California, New York, and Massachusetts; city dwellers and farm boys; violinists, painters and football players; biologists, historians and classicists; potential stockbrokers, academics and politicians. The result was that very few ethnic or racial minorities attended Harvard College. In recent years Harvard College has expanded the concept of diversity to include students from disadvantaged economic, racial and ethnic groups. Harvard College now recruits not only Californians or Louisianans but also blacks and Chicanos and other minority students. Contemporary conditions in the United States mean that if Harvard College is to continue to offer a first-rate education to its students, minority representation in the undergraduate body cannot be ignored by the Committee on Admissions.

In practice, this new definition of diversity has meant that race has been a factor in some admission decisions. When the Committee on Admissions reviews the large middle group of applicants who are "admissible" and deemed capable of doing good work in their courses, the race of an applicant may tip the balance in his favor just as geographic origin or a life spent on a farm may tip the balance in other candidates' cases. A farm boy from Idaho can bring something to Harvard College that a Bostonian cannot offer. Similarly, a black student can usually bring something that a white person cannot offer. The quality of the educational experience of all the students in Harvard College depends in part on these differences in the background and outlook that students bring with them.

In Harvard College admissions the Committee has not set target-quotas for the number of blacks, or of musicians, football players, physicists or Californians to be admitted in a given year. At the same time the Committee is aware that if Harvard College is to provide a truly heterogeneous environment that reflects the rich diversity of the United States, it cannot be provided without some attention to numbers. It would not make sense, for example, to have 10 or 20 students out of 1,100 whose homes are west of the Mississippi. Comparably, 10 or 20 black students could not begin to bring to their classmates and to each other the variety of points of view, backgrounds and experiences of blacks in the United States. Their small numbers might also create a sense of isolation among the black students themselves and thus 
make it more difficult for them to develop and achieve their potential. Consequently, when making its decisions, the Committee on Admissions is aware that there is some relationship between numbers and achieving the benefits to be derived from a diverse student body, and between numbers and providing a reasonable environment for those students admitted. But that awareness does not mean that the Committee sets a minimum number of blacks or of people from west of the Mississippi who are to be admitted. It means only that in choosing among thousands of applicants who are not only "admissible" academically but have other strong qualities, the Committee, with a number of criteria in mind, pays some attention to distribution among many types and categories of students.

The further refinements sometimes required help to illustrate the kind of significance attached to race. The Admissions Committee, with only a few places left to fill, might find itself forced to choose between A, the child of a successful black physician in an academic community with promise of superior academic performance, and B, a black who grew up in an inner-city ghetto of semi-literate parents whose academic achievement was lower but who had demonstrated energy and leadership as well as an apparently abiding interest in black power. If a good number of black students much like A but few like B had already been admitted, the Committee might prefer $B$; and vice versa. If $C$, a white student with extraordinary artistic talent, were also seeking one of the remaining places, his unique quality might give him an edge over both $\mathrm{A}$ and $\mathrm{B}$. Thus, the critical criteria are often individual qualities or experience not dependent upon race but sometimes associated with it.

In the pages that follow I will describe how I stumbled on this remarkable work of advocacy, explain why I can state with confidence that Justice Powell was influenced by Cox' diversity argument in 1974, and reveal how Archibald Cox and his talented collaborators articulated a set of policies that set Harvard apart from other selective colleges in its approach to affirmative action. These policies reached back to Harvard's approach to recruitment of students in the nineteenth and early twentieth centuries, long before the deplorable Jewish quota of the 1920's and 30 's, and were central to its mission as a university in both the 1960 's and as far back as the 1860 's, as well as today. 


\section{REDISCOVERING THE ARCHIBALD COX AMICUS CURIAE BRIEF IN DEFUNIS V. ODEGAARD}

Although I have been writing about affirmative action for nearly forty years, ${ }^{20}$ this project began just a few years ago, in a Paris café. I was having lunch with Laure Bereni, a French scholar who studies the sociology of inequality. ${ }^{21}$ We were talking about the difficulty of harmonizing the dominant French view of equality, which denies the legitimacy of the idea of racial identity, ${ }^{22}$ with the growing French endorsement of corporate diversity management. ${ }^{23} \mathrm{I}$ mentioned off-handedly that the entire idea of diversity as a justification for race-conscious selection policies came from the Bakke case. Laure replied that she suspected I was correct, but to her knowledge no one had ever established the link. Yes, companies started adopting diversity management policies after the Bakke case was decided, but they didn't acknowledge Bakke as their source, and instead claimed that diversity management was based on business principles, not legal principles, and was unrelated to compliance with civil rights laws.

This was intriguing to me, so when I returned to Berkeley I gathered a group of students to see if we could find a link between the diversity justification for affirmative action set out in the Bakke decision and the development of diversity management as a business strategy, a project I

${ }^{20}$ See, e.g., Michael K. Brown ET AL., Whitewashing Race: The Myth OF A COLOR-BLIND SOCIETY (University of California Press 2003); DAVID OPPENHEIMER eT AL., COMPARATIVE EQuality AND ANTI-Discrimination LAW: CASES, COdES, CONSTITUTIONS And COMMENTARY (Foundation Press 2012) (2d ed.2017); David B. Oppenheimer, Distinguishing Five Models of Affirmative Action, 4 BERKELEY WOMEN's L. J. 42 (1988); David B. Oppenheimer, Understanding Affirmative Action, 23 HASTING CONST. L. Q. 921 (1996); David B. Oppenheimer, Inclusiveness, Interrelatedness, and the Affirmative Action Debate in California - Introduction to the GGU School of Law Symposium on Race Relations in America, 27 GOLdEN GATE U. L. REV. 287 (1997); David B. Oppenheimer, Carcieri's Self-Described "Progressive" Critique of the ACLU on Proposition 209: A "Conservative" Response, 39 SANTA CLARA L. REV. 1153 (1999); David B. Oppenheimer, The Legality of Promoting Inclusiveness: Why the University of California May and Should Use Race and Ethnicity as Factors in Applicant Outreach, 27 CHICANA/O LATINA/O L. REV. 11 (2008); David B. Oppenheimer, Color-Blindness, Racism-Blindness, and Racism-Awareness: Revisiting Judge Henderson's Proposition 209 Decision, 13 Berkeley J. Afr. AM. L \& POL'Y. 229 (2011); David B. Oppenheimer, The Disappearance of Voluntary Affirmative Action From the US Workplace, $24 \mathrm{~J}$. POVERTY \& SOC. JUST. 37 (2015).

21 For more information about Laure Bereni, please visit https://www.cmh.ens.fr/Bereni-Laure.

${ }_{22}$ See David B. Oppenheimer, Why France Must Collect Data on Racial Identity ... in A French Way, 31 HASTINGS INT'L \& COMP. L. REV. 735 (2008).

${ }^{23}$ See THE DIVERSITY CHARTER, Charte de la diversité en enterprise (The French Diversity Charter) (2018), http:/www.diversity-charter.com/. 
continue to pursue. Our group included graduate law students and undergraduate political science and history students. They are listed in the acknowledgment section of this article, where I express my deep gratitude for their work.

We began our search by looking for uses of the term "diversity" in legal cases or commentary prior to the Bakke case. We found very few citations, but we did find one very important reference: a highly relevant 1974 article by Richard Posner, the great conservative legal scholar from the University of Chicago (who continues to teach at Chicago and to publish many books and articles, and who, until his retirement in 2017, simultaneously served as a judge on the United States Court of Appeals for the Seventh Circuit). ${ }^{24}$ Posner's article concerned the DeFunis case, which has been largely overlooked by legal scholars because the Supreme Court dismissed it as moot. ${ }^{25}$

Marco DeFunis, like Allan Bakke, was a white applicant to a public university professional school who believed he had been rejected in favor of a non-white candidate because of affirmative action. In Bakke's case, it was the University of California's medical school at Davis. In DeFunis' case, it was the University of Washington's law school. Like Bakke, DeFunis had won in the trial court and had been allowed to begin school while waiting for the appellate courts to act. But in the DeFunis case, by the time the case reached the Supreme Court he was within a few months of graduation. When the lawyers for the University of Washington assured the Court that he would be allowed to graduate regardless of their ruling, the Court dismissed the case as moot.

Posner's article largely focused on the substantive equality arguments made by the University of Washington and its supporters: that affirmative action was a necessary remedy to our long history of discrimination against Black Americans. But he also included an argument on why racial diversity does not justify race-conscious college admissions. Since this was written in 1974 , prior to the brief by the four elite universities in the Bakke case, my first reaction was to ask, "why would he bother to refute an argument that (I thought) hadn't yet been made?" That is, who was Posner refuting? Posner wrote that, "A frequently suggested basis for preferential treatment is the desire to increase the diversity of the student body in the hope of thereby enhancing the quality of the students' educational experience." ${ }^{26}$ Despite his use of the word "frequently," his citation was to a single source, but what a source it was. He cited a brief he described as having been filed in the DeFunis case by

${ }^{24}$ Richard A. Posner, The DeFunis Case and the Constitutionality of Preferential Treatment of Racial Minorities, 1974 SUP. CT. REV. 1 (1974).

${ }^{25}$ Defunis v. Odegaard, 416 US 312, 319-20 (1974). The decision to dismiss the case as moot was controversial. Four members of the Court, led by Justice Douglas, dissented from the dismissal.

${ }^{26}$ Posner, supra note 24 , at 8 . 
Harvard University. Clearly, I had to read this brief. It turned out to be harder to find than I could have imagined.

My first step was to log on to Westlaw, the legal database that provides copies of every brief filed in the U.S. Supreme Court. It took only a minute to find the many briefs in the DeFunis case, and yes, there was a brief filed by Harvard University on behalf of its Center for Law and Education. I eagerly pulled it up and began reading. It was a good brief, and I was enjoying reading it ${ }^{27}$ but the further I read the more confused I became. Where was the discussion of diversity? Not in this brief. By the time I finished reading, I concluded there must have been two Harvard briefs. A further search on Westlaw revealed, however, that if there were two briefs, Westlaw had only published one of them.

This was peculiar. I wouldn't expect Westlaw to leave out one of the briefs. But I wasn't yet concerned. I logged on to LexisNexis, Westlaw's chief rival, confident I would find the brief there; I didn't. Just as with Westlaw, LexisNexis had the brief from the Harvard University Center for Law and Education, but nothing else from Harvard.

Fortunately, my office is just a few steps from one of the great law libraries of the world. I knew that the Berkeley Law Library was a repository for "hard copies" of every brief filed in the U.S. Supreme Court. It might be dusty, but surely it would be there. I phoned the library to ask if someone there could pull the briefs from the DeFunis case. The answer was a shock. The Library had stopped collecting the hard-copy briefs, relying exclusively on Westlaw and LexisNexis. If it wasn't online, it was as if it didn't exist.

I was still sitting in my office in a state of shock a few minutes later when the phone rang. It was I-Wei Wang, one of our amazing librarians. Had I been looking for the briefs in the DeFunis case? Yes. Well, it turned out that legal historian Anne Fagan Ginger, on behalf of the Council on Legal Education Opportunity (CLEO), thinking in 1974 that the case might be historically important, had published the record of the case, including the full set of briefs, as a three-volume set. ${ }^{28}$ They were sitting in my office ten minutes later. I've since learned from Professor Ron Levin at Washington University that the brief is also included in Landmark Briefs and Arguments of the Supreme Court of the United States, edited by Kurland and Casper. ${ }^{29}$

The full set of briefs confirmed what I had suspected: there were two Harvard briefs. One was the brief by the Harvard University Center for Law and Education, which was available online. The other was filed on behalf of the President and Fellows of Harvard College. I eagerly began

${ }^{27}$ I leave it to the reader to decide whether that says more about me than it does about the brief.

${ }^{28}$ DEFUNIS VERSUS ODEGAARD, supra note 12.

${ }^{29}$ LANDMARK BRIEFS AND ARGUMENTS OF THE SUPREME COURT OF THE United States: Constitutional LaW (Gerhard Casper \& Philip B. Kurland eds., 1975). 
reading it. Parts of the brief covered familiar ground, though it covered it particularly well. Well-structured and persuasively written, clearly this was the work of a master advocate. ${ }^{30}$

But the major argument of the brief was a complete shock. Here was the diversity argument adopted by Justice Powell in the Bakke case, fully formed. With a sense of déjà vu, I felt like I was reading parts of the famous appendix to the Powell opinion (as indeed I was), but the Bakke case would not arrive at the Court for another four years. A careful rereading revealed that pages $14-17$ of the brief, a total of just over 1,000 words, had simply been lifted by the authors of the Bakke amicus brief and attached to their brief as an appendix, named the "Harvard College Admissions Program" and described (correctly) in a footnote as "a description of the criteria applied in selecting students for admission to Harvard college." Thus, the Bakke/Harvard appendix, which has become the standard description of the diversity justification for affirmative action, is not an official publication of the Harvard admissions office, but rather an advocate's description in an amicus curiae brief of how Harvard operates.

One phrase stood out in particular. The brief argued that, "A farm boy from Idaho can bring something to Harvard College that a Bostonian cannot offer. Similarly, a black student can usually bring something that a white person cannot offer." Justice Powell's quotation of that line in his Bakke opinion would become one of the most widely recognized quotes about affirmative action in the decades of debates that followed. In time, I would discover that there really was a farm boy from Idaho, and I'd get to interview him and learn how he earned a full scholarship to Harvard College, and eventually rose to be its Dean.

When I finished reading the brief and turned to the signature page, I was thrilled and delighted to find that Archibald Cox was the author. What a great brief by such a leading light of the law. What a wonderful coincidence that Richard Nixon's Watergate meltdown led to Cox writing it. And I shouldn't ignore the contribution of his three young coauthors: Daniel Steiner, James Sharaf, and James Bierman. Steiner, then 29, was in his third year as Harvard University General Counsel. ${ }^{31}$ Sharaf, then in his mid-30's, was Harvard University Assistant General Counsel. Bierman, then 28, was the Harvard Law School Assistant Dean and Associate Director of Admissions and Financial Aid.

My excitement was tempered by my recognition that the most important contribution of the DeFunis brief was probably its adoption by the authors of the Bakke brief, among them its co-author Daniel Steiner.

${ }^{30}$ See Cox Brief, supra note 1. Don't trust my description, read it yourself; you can find it as an appendix to this article.

${ }^{31}$ Steiner would look to the Court's adoption of the Harvard diversity model as a "moment of particular meaning to me." Daniel Steiner Dies at 72, HARV. GAZETTE (June 15, 2006), https:/news.harvard.edu/gazette/story/2006/06/daniel-steiner-dies-at-72/. 
It's not as if Justice Powell likely paid any attention to the brief, I reasoned, given that the DeFunis case was dismissed as moot. There were thirty-two amicus briefs in the DeFunis case, ${ }^{32}$ plus the briefs of the parties. Was there any reason, I asked myself, to think that Justice Powell even saw this particular brief, let alone read it? In an earlier age, these questions would have stumped many scholars, or led to many hours of work for those few with the fortitude to track down Justice Powell's files. But thanks to the internet, within a few minutes I was reading Justice Powell's file from the DeFunis case. ${ }^{33}$

And there it was. Halfway through the file was a memo from Justice Powell's law clerk John C. Jeffries Jr., now a distinguished professor at the University of Virginia, suggesting he pay particular attention to the "brief by Archibald Cox for Harvard College," with a red check mark over Cox's name added by Justice Powell. ${ }^{34}$

As the DeFunis case was pending and the arguments about affirmative action were heating up in the body politic, New York Times columnist Anthony Lewis, a two-time winner of the Pulitzer prize, wrote a Times column on March 3, 1974 describing and promoting the diversity justification, specifically referencing and quoting the Cox/Harvard brief (so Posner was right, it was being frequently discussed). I later learned that when Cox was drafting the brief, he frequently had lunch with Lewis, who was in residence at Harvard that semester. How did I find the Anthony Lewis column - through a careful search of the Times archive? No, Justice Powell had clipped it and added it to his DeFunis file. ${ }^{35} \mathrm{He}$ 'd done the same with an article in Newsweek by Jerrold K. Footlick, which also highlighted the diversity argument. ${ }^{36}$

Did Justice Powell remember the Cox brief four years later, when the Bakke case arrived at the Court? An examination of Justice Powell's Bakke files confirms that he did. ${ }^{37}$ The Cox/Harvard brief from DeFunis

\footnotetext{
${ }^{32}$ Assuming Ann Fagan Ginger included all of them.

33 Justice Powell's DeFunis v. Odegaard File, WAshington And LeE UNIVERSITY SCHOOL OF LAW, available at http://aw2.wlu.edu/deptimages/powell\%20archives/73235_DefunisOdegaard.pdf [hereinafter Justice Powell's DeFunis archives].

${ }^{34}$ Memorandum from John C. Jeffries, Jr. to Justice Powell (Feb. 12, 1974), in Justice Powell's DeFunis archives at 32.

${ }^{35}$ Anthony Lewis, The Legality of Racial Quotas: Who Will Pay for the Injustice of the Past?, N.Y. TIMES (Mar. 3, 1974), http://www.nytimes.com/1974/03/03/archives/the-legality-of-racial-quotastough-intellectual-issues.html?_r $=0$, reprinted in Justice Powell's DeFunis archives at 45 .

${ }^{36}$ Jerrold K. Footlick, Justice: Racism in Reverse, NEWSWEEK, 1974, reprinted in Justice Powell's DeFunis archives at 68 (identifying Cox as a principal amicus brief author, and quoting the language from the Cox brief about the "farm boy from Idaho.").

${ }^{37}$ See Justice Powell's Regents of the University of California v. Bakke File, WAShington AND LeE UNIVERsity SchOOL OF LAW,
} 
clearly influenced his views four years later. The files include a memo dated August 29, 1977 to Justice Powell from Bob Comfort, one of his law clerks. ${ }^{38}$ That memo extensively discusses the diversity rationale for race-conscious affirmative action, repeatedly cites as authority the "Brief for Harvard College in DeFunis," and refers to the "Idaho farm boy" analogy. ${ }^{39}$ The memo concludes with a recommendation that the diversity justification offers "the best opportunity for taking a middle course." Justice Powell underlined that phrase and, referring to the Cox/Harvard brief, added in the margin, "This is the position that appeals to me. Use DeFunis."

Clearly, Justice Powell was ready for the Bakke briefs asserting a diversity justification for affirmative action; he'd been waiting for them. And while his citation to the Harvard College admissions plan in his Bakke opinion was to the four-university brief in the Bakke case, I now realized that he was relying on the description of Harvard's affirmative action program that had been lifted right from the Cox/Harvard brief he had already read and admired in the DeFunis case.

This led me to two questions, which I will address in Parts II and III of this article. First, what were the sources for Cox's description of Harvard's affirmative action program? Second, how far back did Harvard's diversity policies go?

\section{WHAT WERE THE SOURCES FOR COX'S DESCRIPTION OF HARVARD'S AFFIRMATIVE ACTION PROGRAM?}

In drafting his explanation of how race-based affirmative action was part of a broader policy of promoting diversity in admissions, Cox was describing a process developed and nurtured by three remarkable men who were trained in admissions, and then took turns serving as Dean of Harvard College between 1947 and $1967 . .^{42}$ This twenty-year period was a time of enormous change in the world of college admissions. In 1947, as the post-war surge of veterans was declining, the critical challenge for

http://aw2.wlu.edu/powellarchives/page.asp?pageid $=1322$ [hereinafter Justice Powell's Bakke archive].

${ }^{38}$ See Memorandum from Bob Comfort to Justice Powell (Aug. 29, 1977), in Justice Powell's Bakke archives, supra note 37, at folder 2 [hereinafter Comfort Bakke Memo].

${ }^{39}$ See id. at $30-40,55,58-59,61$.

${ }^{40} I d$. at 58.

${ }^{41} \mathrm{Id}$.

${ }^{42}$ The position of Dean of Harvard College during this period is comparable to Dean of Students at many institutions. The governance structure at the relevant time included a Dean of Harvard College and a Dean of the Faculty of Arts and Sciences who reported to the Provost who, in turn, reported to the President, who reported to both the faculty and the Board of Overseers of the Harvard Corporation. 
admissions offers was recruitment; ${ }^{43}$ Harvard and other elite colleges admitted over half of the students who applied. ${ }^{44}$ By 1967, as the baby boomers were reaching college age and the percentage of Americans attending college was skyrocketing, Harvard and its peers had become "highly selective colleges," admitting only a small percentage of their applicants. ${ }^{45}$

The first of the three deans, Wilbur J. Bender, grew up in Goshen, Indiana, and spent his first two years of college at a small religious college near home before transferring to Harvard. ${ }^{46}$ After graduating from Harvard College in 1927, he helped organize the school's scholarship program, becoming an advocate for opening Harvard to low-income students. ${ }^{47}$ He returned to Harvard after military service in World War II to counsel veterans as Harvard's enrollment expanded and diversified to meet the demand of the many vets taking advantage of the GI Bill. ${ }^{48} \mathrm{He}$ was appointed Dean of the College in 1947 and served as Dean until 1952 when he was appointed Dean of Admissions and Financial Aid, ${ }^{49}$ a position he held until 1960.

Drawing from his experience as someone who arrived at Harvard from outside the usual private New England prep school pipeline, from his work counseling veterans from many backgrounds, and from his years as Dean of the College and Dean of Admissions and Financial Aid, Bender was a strong advocate for regional, experiential, and class diversity in admissions. As Dean of Admissions, he argued in a highly public and celebrated dispute over Harvard's future with a faculty faction who wanted to make admissions decisions based entirely on high school grades and standardized test scores ${ }^{50}$ He insisted that Harvard's strength came from its diversity. Looking ahead to the occupations of Harvard's future alumni, he wanted a mix of (1) brilliant students, who he de-

${ }^{43}$ See, e.g., Douglas M. Fouquet and Bayley F. Mason, Intense Ivy Rivalry for "Elite" of Applicants Puts Harvard Eyes on Nation-Wide Promotion, HARV. CRIMSON (June 21, 1951), http://www.thecrimson.com/article/1951/6/21/intense-ivy-rivalry-for-elite-of.

${ }^{44}$ See Fred L. Glimp, Final Report to the Faculty of Arts and Sciences, in 65 Official Reg. HaRV. U., No. 25, 90, 103 (1968) (on file with the author and the editors of this journal) (reporting that, during 1951-52, Harvard accepted 1,940 of its 3,089 applicants $(62.8 \%)$ ).

${ }^{45}$ See id. (reporting that, by 1966-67, Harvard College accepted just 1,402 of its 7,082 applicants $(19.6 \%)$ ).

${ }^{46}$ William J. Bender '27 Dies at 65 A Dean at Harvard for 13 Years, HARV. CRIMSON (Apr. 7, 1969), http:/www.thecrimson.com/article/1969/4/7/wilbur-jbender-27-dies-at.

${ }^{47} \mathrm{Id}$.

${ }^{48} \mathrm{Id}$.

${ }^{49} \mathrm{Id}$.

${ }^{50}$ For a full account of that dispute, see KARABEL, supra note 8, at 248293. 
scribed as the "top one percent" ue their studies as graduate students and become professors; (2) future business leaders; and (3) future government leaders, like the two President Roosevelts, and the soon-to-be-elected President Kennedy. He extolled the diversity of Harvard's incoming classes as a mix of these groups, and others, and warned against simply becoming a proving ground for the professorate. ${ }^{52} \mathrm{He}$ also warned that Harvard was becoming a rich and upper middle class enclave, and called for an expansion of scholarships. ${ }^{53}$

The second dean, Fred L. Glimp, grew up on a farm in Idaho, and came to Harvard after serving in the U.S. Army Air Corps during World War II. ${ }^{54}$ After earning his bachelor's degree in 1950 and studying at Cambridge University on a Fulbright Scholarship, he returned to Harvard in 1954 as an admissions officer, working under Bender. ${ }^{55}$ In 1960, when Bender stepped down as Dean of Admissions and Financial Aid, Glimp succeeded him. ${ }^{56}$ Like Bender, Glimp was deeply committed to diversity in Harvard College admissions. Drawing on his own experience as a farm boy from Idaho and a war veteran, he wanted to expand the pipeline of who came to Harvard, and to make sure the College could provide the financial resources to permit poor and middle class students to attend. ${ }^{57}$ In advocating for diversity, Glimp embraced the arguments made by Bender, and added two more. First, he argued, the educational experience of the students and faculty would be enhanced if the students attending the College came from all regions of the country, all walks of life, and all economic classes, and brought many kinds of talent and experience to the community. ${ }^{58}$ Second, he was deeply skeptical of the value of high school grades and test scores as an indicator of future success, especially among students from middle class and poor families. ${ }^{59}$

The third of the Harvard Deans, John U. Monro, graduated from Harvard in $1934 .{ }^{60}$ Like Bender and Glimp, he was a World War II veter-

${ }^{51}$ See KARABEL, supra note 8, at 279-285; Ex-Dean Bender's Valedictory Message, HARV. CRIMSON (Oct. 2, 1961), http://www.thecrimson.com/article/1961/10/2/ex-dean-benders-valedictorymessage-pexcerpts-from.

${ }^{52}$ See infra notes 84 through 86 and accompanying text.

${ }^{53} \mathrm{Id}$.

${ }^{54}$ Interview with Fred Glimp by David McClintick, Harvard University, John Harvard's Journal (Jan. 1997).

${ }^{55} \mathrm{Id}$.

${ }^{56} \mathrm{Id}$

${ }^{57} \mathrm{Id}$.

${ }^{58}$ See infra note 87 and accompanying text.

${ }^{59} \mathrm{Id}$.

${ }^{60}$ Richard Severo, John U. Monro, 89, Left Harvard to Follow Ideals, Dies, N.Y. TIMES (Apr. 3, 2002), http:/www.nytimes.com/2002/04/03/us/john-umonro-89-dies-left-harvard-to-follow-ideals.html. 
an, earning a Bronze Star as a naval officer. ${ }^{61}$ Like Bender, he returned to Harvard after the war to counsel incoming veterans. ${ }^{62}$ In 1950, three years after Bender began as Dean of the College, Monro was named Director of Financial Aid. ${ }^{63}$ In 1958, he was named Dean of the College. ${ }^{64}$ At that point, Monro was Dean of the College, Bender was Dean of Admissions and Financial Aid, and Glimp was working with Bender in admissions (and would succeed him in 1960). Monro remained Dean of the College until 1967. ${ }^{65}$ Thus, from 1960-67, Monro was Dean of the College while Glimp was Dean of Admissions and Financial Aid, and for most of the period from 1947-67 the two key positions of Dean of Harvard College and Dean of Admissions and Financial Aid were held by a combination of Bender, Glimp, and Monro.

For the purpose of understanding race-based affirmative action at Harvard, Monro was the most important of the three deans. His importance has not received the recognition it deserves, perhaps because he left Harvard at the height of his career to move to a college that gets far less attention. It was Monro who reached back to the nineteenth century to bring racial diversity back into the core of Harvard's values. He did so because the struggle against racism was fundamental to who he was.

In 1948 Monro began organizing summer recruiting trips, first to Chicago and then to the South, to recruit Black students to Harvard. ${ }^{66}$ This should be rightfully regarded as the beginning of race-conscious affirmative action at Harvard, although the school's commitment to diversity (including racial diversity) began far earlier. Monro joined the board of directors of the National Scholarship Service and Fund for Negro Students (NSSFNS), ${ }^{67}$ and even as he was rising to his position as Dean of Harvard College, he was spending more and more of his time focused on improving educational opportunities for Black Americans.

In 1949, Monro recommended that Harvard identify promising Black high school seniors and offer them financial assistance. ${ }^{68} \mathrm{He}$ believed working with Black leaders in major metropolitan areas would enable this, and proposed the goal of 10 Black recruits per freshman class. ${ }^{69}$ In 1953, Monro was able to convince Harvard to work with the NSSFNS. As a result, Black enrollment figures rose and by the late

${ }^{61} \mathrm{Id}$

${ }^{62}$ Id; see also TONI-LeE CAPOSSElA, John U. MONRO: UnCOMMON EDUCATOR (2012).

${ }^{63}$ Boisfeuillet Jones Jr., Monro to Resign July 1 as Dean of College; Glimp Will be Recommended as Successor, HARV. CRIMSON (Mar. 10, 1967), http://www.thecrimson.com/article/1967/3/10/monro-to-resign-july-1-as.

${ }^{64}$ CAPOSSELA, supra note 62, at 65.

${ }^{65}$ Id. at 119; see also Boisfeuillet Jones Jr., supra note 63.

${ }^{66}$ CAPOSSELA, supra note 62 , at 55-58.

${ }^{67} \mathrm{Id}$. at 56.

${ }^{68} \mathrm{Id}$. at $55-58$.

${ }^{69}$ KARABEL, supra note 8 at 400 . 
1950 's, as many as half of the college's black applicants were reporting they had worked through the NSSFNS. ${ }^{70}$ Between 1948 and 1960, 94 Black students entered Harvard. ${ }^{71}$

In 1962, Monro attended an American Teachers Association (ATA) conference, where he met ATA president Lucius Pitts. Pitts was nearing the end of his first year as president of Miles College, a historically Black college in Birmingham, Alabama. Pitts invited Monro to visit Miles. ${ }^{72}$ On September $4^{\text {th }} 1963$, Monro arrived at Miles for a faculty workshop. This was the same day the federal court order requiring the desegregation of Birmingham's schools took effect. That morning, five Black students at three different schools faced violent crowds and empty classrooms. ${ }^{73}$ Consequently, an armed guard patrolled Miles. ${ }^{74}$ It would be less than two weeks later, on September $15^{\text {th }}$, that a KKK bomb would kill four Black girls in the basement of Birmingham's Sixteenth Street Baptist Church.

During his visit, Monro met with Pitts and about fifteen others in another church basement to discuss a statement, intended for the mayor, regarding the school desegregation disaster. There was suddenly a loud explosion. A bomb had exploded at the home of Arthur Shores, the attorney leading the desegregation case. Monro found himself walking up the hill to Shores' house with Pitts and an angry Black crowd. He later explained that that day, he got his "own first-hand look at the fury, unity, and determination of the city's Black community." 75 He pledged to help develop a new freshman studies program at Miles College, and to return as needed to complete the project. ${ }^{76}$

Over the remainder of the year, Monro returned to Miles every month to plan a Freshman Studies Program. ${ }^{77} \mathrm{He}$ also committed to directing the English section of a pre-college workshop developed by Pitts. In the summer of 1964, Monro assisted in organizing a new tutoring program co-taught by Harvard and Miles students. They tutored elementary school students in Birmingham in ten teams, each with one Harvard student and one Miles student. ${ }^{78}$

Inspired by his summer at Miles, Monro continued his efforts to support civil rights and Black students at Harvard. He helped fund the Southern Courier, a Harvard student newspaper providing coverage of

${ }^{70} \mathrm{Id}$

71 Charles W. Puttkammer, Negroes in the Ivy League 15-16 (1962) (unpublished manuscript) (on file at Harvard University Library).

${ }^{72}$ Severo, supra note 60.

${ }^{73}$ CAPOSSELA, supra note 62, at 91-92.

${ }^{74}$ Id.

${ }^{75}$ CAPOSsELA, supra note 62, at 108 (quoting John U. Monro's "Miles College Assembly Speech").

${ }^{76} \mathrm{Id}$.
${ }^{77} \mathrm{Id}$. at 96.
${ }^{78} \mathrm{Id}$. at $97-101$. 
civil rights. Enrollment numbers of Black students continued to increase, with 42 Black freshmen entering Harvard in $1965 .{ }^{79}$ Though I have no evidence to connect Monro's advocacy at Harvard College with Harvard Law School Dean Erwin Griswold (who, like Cox, would later serve as U.S. Solicitor General), it was also in 1965 that Griswold launched the first American law school affirmative action program. ${ }^{80}$

Meanwhile, Monro continued to work on the Miles College Freshman Studies Program, becoming a trustee at Miles. When the summer of 1965 came, Monro had molded his teaching around the needs of Miles students. His reading list included several Black authors, and he pushed for the general inclusion of Black literature in American education at a College Board conference later that summer. ${ }^{81}$ Monro agreed to return to Miles the next summer to direct the entire precollege workshop including the social studies and math sections. The following winter, Pitts invited him to run the Freshman Studies Program. ${ }^{82}$ Monro accepted and decided he would move to Alabama permanently.

On March 9, 1967, Monro announced that starting July 1, 1967, he would become Director of Freshman Studies at Miles. When asked why he was interested in moving from Harvard to Miles, Monro replied, "Well, I decided that my job at Harvard is like being a shock absorber in a Rolls Royce. But the really serious issues today are being faced by blacks, and I want to be part of that." ${ }^{, 83}$ That coming year, the number of incoming Black freshmen at Harvard would rise to $51{ }^{84}$ By 1970 it would reach 98. ${ }^{85}$ Although Monro left Harvard in 1967, his legacy remained in the expanding importance of racial diversity as a part of Bender and Glimp's vision of diversity, which was becoming increasingly important to how Harvard should select its incoming students.

In drafting the DeFunis amicus brief, Cox relied on this twenty-fiveyear history of embracing diversity in admissions, with an increasing focus on racial and ethnic diversity. He drew on his own observations as a member of the Harvard faculty, and as an observer of the 1959-60 debate between Bender and the faculty faction who favored admitting students based solely on grades and test scores. He relied on a series of discussions with Harvard admissions officers and faculty. He relied on a

${ }^{79}$ KARABEL, supra note 8 , at 401 .

${ }^{80}$ See William G. Bowen \& Derek BoK, The Shape of the River: LONG-Term CONSEquences OF CONSIDERING RaCe IN COllege AND UNIVERSITY ADMISSIONS 5 (1998).

${ }^{81}$ CAPOSSELA, supra note 62, at 135.

${ }^{82} \mathrm{Id}$. at 118.

${ }^{83}$ Ken Gewertz, Champion of Disadvantaged, Monro, dies at 89, THE HARV. GAZETTE (Apr. 11, 2002), https:/news.harvard.edu/gazette/story/2002/04/champion-of-disadvantagedmonro-dies-at-89/.

${ }^{84}$ KARABEL, supra note 8, at 403.

${ }^{85}$ Id. at 404 . 
developing case law about racial segregation and academic freedom, discussed below at page 205. And he relied on, and cited, the final reports prepared by the outgoing admissions deans for the Harvard faculty, submitted in 1960 by Dean Bender and 1968 by Dean Glimp. Between them, the two reports thoroughly covered the sixteen years in which the post-war diversity policies, including a growing commitment to racial and ethnic diversity, became a defining part of Harvard's mission.

In Bender's case, when he stepped down in 1960, he issued a controversial report highlighting his views, and criticizing those who would restrict admission to the best academic candidates, as measured by grades and test scores. As he put the question,

Should the ultimate goal of Harvard's admission effort be to come as close as possible to a student body all of whom would have outstanding academic ability, all of whom would be, as one member of the special faculty committee put it, in the top 1 per cent, or even better, the top half of 1 per cent, of American College students? ... Or should we consciously aim for a student body with a somewhat broader range of academic ability, perhaps the top 5 per cent of American college students, a student body deliberately selected within this range of ability to include a variety of personalities, talents, backgrounds and career goals? ${ }^{86}$

His preference was for an admissions policy that valued

a Harvard College with a certain range and mixture and diversity in its student body - a college with some snobs and some Scandinavian farm boys who skate beautifully and some bright Bronx premeds, with some students who care passionately if unwisely (but who knew about editing the Crimson or beating Yale), or who have ambition to run a business and make a million, or to [be] elected to public office, a college which not all the students have looked on school just as preparation for college, college as preparation for graduate school and graduate school as preparation for they know not what.

${ }^{86} I d$. at 615 (as Karabel explains in footnote 216 , there are multiple versions of Dean Bender's final report. By combining the 1959-60 report to the faculty found on the website of the Harvard University Archives with a portion of that report not found on the website but secured by the Berkeley Law Library and now in my possession, I believe I have the full report. This portion appears at page 56 of the report in my files. Another abbreviated version can be found at Wilbur J. Bender, The Top-One-Percent Policy, Harvard Alumni Bulletin (Sept. 1961) at 21-25). 
Won't even our top-one-per-cent be better men and better scholars for being part of such a college ${ }^{87}$

Decoding the stereotypes embedded in Bender's prose, he called for an admissions policy that makes room for (1) the top students in the country as measured by grades and test scores, who were likely to become academics and/or scientists; in addition to (2) geographic diversity, with an emphasis on rural students and those from outside New England and the Middle Atlantic states; ${ }^{88}$ (3) socio-economic diversity; (4) athletes (in this example, hockey players); (5) Jewish students; (6) sons of alumni; (7) students likely to be future business leaders; and (8) students likely to be future political leaders, even if it meant including students not in the top one percent academically. And, he was arguing that Harvard and its best students would benefit from this diversity among its students.

The second report Cox relied on was submitted by Glimp as he was moving from Dean of Admissions and Financial Aid to Dean of Harvard College in 1967. It fully addressed the role of diversity in admissions. It was written as affirmative action programs were just beginning nationally, and before they had become controversial. But at that point Harvard had been making special efforts to recruit Black students for nearly twenty years, since Monro's recruiting trips beginning in 1948. Dean Glimp's focus is on diversity in the broadest sense, with only a brief reference to race. Yet it does include racial diversity, along with many other sorts, as a form of diversity that he saw as contributing to the success of Harvard College. Because of its importance to the Cox brief, I quote from it here at length.

The basic question confronting the Committee was how to choose among many more highly qualified applicants than we have room to accept - highly qualified not only in terms of objective indices of academic promise, and the often helpful comments of teachers about their students' intellectual characteristics, but also in an unusual range of non-academic talents, backgrounds, and personal strengths, styles and promise. The Committee's response has been to seek variety in making its choices. This has seemed important in part because it is consistent with the educational mission of the College, in

${ }^{87}$ The language quoted is found in the portion of the report provided by the Berkeley Law Library at page 73, and also published in the Harvard Crimson contemporaneously, and available on its website; see Ex-Dean Bender's Valedictory Message, HARV. CRIMSON (Oct. 2, 1961), http://www.thecrimson.com/article/1961/10/2/ex-dean-benders-valedictorymessage-pexcerpts-from/?page $=2$.

${ }^{88}$ This argument for geographic diversity was a key excuse for the Jewish quota, see infra pp. 194-95. 
part because it adds a critical ingredient to the effectiveness of the educational experience here. The Committee's notion of the educational mission of the College has continued to be the historical one - that in addition to the relative handful of men whose intellectual potential will seem extraordinary to the Faculty (presently perhaps as many as 150 men in a class) we have tried to admit men who seemed likely to be promising and effective in the long run in a variety of areas - law, politics, public service, teaching, and research, business, writing and other creative arts, medicine and so on. The effectiveness of our students' educational experience has seemed to the Committee to be affected as importantly by a wide variety of interests, talents, backgrounds and career goals as it is by a fine faculty and our libraries, laboratories and housing arrangements.

These basic considerations and the recent changes in our admission situation led the Admission Committee early in the 1960 's to make a conscious effort to try to maintain the range of measured ability in entering classes. For ten years, surely longer, the threshold of acceptable measured ability for Harvard had been rising steadily and it seemed important for several reasons to be cautious about raising the threshold further. For example, in the Class of 1956,90 percent of our students came from the top 12 to 14 percent of their age group (the top 18 percent of high school seniors), but in the Class of 1965 the same proportion of the Class came from the top 3 or 4 percent of the age group (the top 5 percent of seniors).

The Committee also had several specific considerations in mind. First, it seemed to the Committee that by any meaningful standard this new $10^{\text {th }}$ percentile student (the man at the top of the bottom tenth of the class) had unusual ability indeed - certainly enough ability to be a highly effective man in almost any area of American life, and occasionally even a man whose academic work here would lead his department to feel that his performance was of summa quality.

Second, it became clear to the Committee that students representing some of the most important elements of Harvard's socio-economic diversity - students whom the admission staff and our alumni schools committeemen were working hard to recruit- would be cut out disproportionately with much of a further narrowing of the range of measured ability. These were the students 
from seriously disadvantaged backgrounds, from rural areas, and from blue-collar families....

Third, if one assumes that truly unusual personal strengths are rare, a further narrowing of the range of admissible ability would reduce drastically the size of the national pool in which we could hope to find the really unusual individual... Although there is no way to be sure, some of us on the Committee have speculated that some combination of Harvard's reputation both for rigor and for human concern, plus the effectiveness of our working alumni around the country, produces for the lowest academic range of our entering classes an unusual proportion of the high schools' most outstanding and eventually promising and effective men. Some of us have even speculated that the lowest tenth of a Harvard class, by measured academic ability, may contain a higher proportion of the most impressive men in the college than any other decile except perhaps the top tenth.

Fourth, a careful review of the academic record of Harvard students shows that in almost every class the lowscoring students receive their degrees about as frequently as high-scoring students. And that a higher proportion of the low-scoring students achieve honor degrees than most laymen would expect....

In two of the last seven graduating classes, for example, the man whose secondary school grades and test scores combined to predict for him the lowest academic record in the class graduated magna cum laude....

\section{$* * *$}

The personal styles and expectations of the students we admit should make Harvard College a conglomeration of many colleges rather than a single one. We want the scholars and scientists who tend to think of the College as a particular department of the Faculty, maybe even as an individual member of the Faculty, or more broadly as a California Institute of Technology (though I am aware that this shorthand does violence to the heterogeneity of the $\mathrm{Cal}$ Tech student body). We need the unusually able, busy students who ran their secondary schools as intellectual or activist leaders - and many of whom will join forces here in the Crimson or the Harvard Undergraduate Council, or whatever, and some of whom will do their best to run or change or be the College. We need 
those whose style is that of the long distance runner, who won't stop working or trying when a reasonable man would, and whose expectation is of a long road of challenges. We need the less precocious high school leaders whose "popularity" and performance seem to grow out of good instincts and concern, whose energy and drive may often be associated (in the special sociology of a socially mobile America) with unusual efforts in athletics or in after-school employment, and who expect Harvard to be a place for a collegiate living and learning and the making of warm friendships - all on some sort of assumption that this broad course can lead them to full and useful lives. We need the promising men from the rural areas and the slums, the men who have very little idea what Harvard is but assume it is "good" and that some combination of what the College offers and the interests and the hopes they bring to it will be worthwhile. These men not only have - and often realize - the greatest opportunity for growth during their undergraduate years, but they represent to their classmates, in a way no instruction can, the difference between the degree of performance that grows out of sheer effort and ability and the component that rests on the accrued advantages of status. We need the talented writers and artists and musicians who will think of the College as a sometimes stimulating, sometimes diverting setting for a Juilliard or a writers' workshop. We need the students who come to the College out of a traditional association with it and who approach the broad experiences of the College with expectations that grow out their understanding of the traditions. And we need the men who care deeply about helping others in an individual personal sense, the kind of men who participate in the incessant reshaping of the efforts of Phillips Brooks House, doing what they feel they ought to do despite the jibes of those who call them do-gooders from one side and the worries of those who think them overly activist on the other. And of course we need Radcliffe, with its own conglomeration of styles and expectations.

It is not just that a diverse heterogeneity in the College is simulating to the Faculty, or more exciting to contemplate than a homogenous undergraduate academy, or more relevant to liberal education - though each of these points is important enough to bear a good deal of the weight of the argument. It is the effects of diversity on students' experiences. A broad diversity in the College 
affords a student enough variety and choice of emphasis and style to preserve his self-respect or humility, or both at different times, and to engage his own interests while he meets the generally high standards and expectations of the College and his fellow students. In short, diversity gives him the choice of enough variety to be himself and to enjoy himself while making the often painful effort to become a man of enough breadth and depth to stand a chance of making a difference in the quality and worth of human life. ${ }^{89}$

In these reports lay the evidence needed by a great advocate like Archibald Cox, with a deep personal understanding of Harvard's history, to describe to the Court and the world beyond what diversity meant to Harvard, and how the admission of students from underrepresented minorities was critical in achieving that diversity. But this was not all that Cox had available to him.

In addition to the Bender and Glimp reports, Cox relied on a series of discussions among his three young co-authors (two from the Harvard counsel's office and the third from the law school admissions office) and a wide range of Harvard administrators and faculty. Among them were some of the top legal thinkers that Harvard had to offer. The sole living co-author, Jim Bierman, recently described the drafting process to me. ${ }^{90}$ Cox met regularly with his co-authors and a number of Harvard professors and administrators to discuss the evolution and current workings of the Harvard College admissions process. ${ }^{91}$ Several were among Cox's closest friends. They included, at various times:

- Harvard President Derek Bok, who had previously served as a law professor and as the Harvard Law School Dean;

- Harvard Law School Dean Albert Sacks;

- Walter Leonard, special assistant to President Bok, who had served as the Assistant Director of Admissions at the School of Law from 1969-71, designed

${ }^{89}$ Fred L. Glimp, Final Report to the Faculty of Arts and Sciences, in 65 OfFicial Reg. HARV. U., No. 25 (1968).

${ }^{90}$ Telephone interview with James ("Jim") N. Bierman, Assistant Dean, Harvard Law School (June 14, 2016).

${ }^{91}$ Id. Jim Bierman has no current recollection of Fred Glimp personally participating in the discussions or drafting, at least those that were held at the Law School, but whether he was in the room or not, his story was. Cox writes in the brief the now-famous line that "a farm boy from Idaho can bring something to Harvard College that a Bostonian cannot offer. Similarly, a black student can usually bring something that a white person cannot offer." He is referring to Glimp, the farm boy from Idaho who was admitted to Harvard College on a scholarship, and rose to be its dean. 
the law school's affirmative action program, and worked with President Bok on developing an affirmative action hiring program for the University; ${ }^{92}$

- Paul Freund, a law professor and leading scholar of Constitutional Law at Harvard; and

- Anthony Lewis, the New York Times columnist and close friend of Cox, who was visiting at Harvard Law School as a lecturer. ${ }^{93}$

Over lunch, with subsequent drafting and redrafting, they worked their way through Harvard's history as it expanded its commitment to diversity to describe to the Court why a diversity justification for affirmative action was intellectually powerful and legally permissible.

Cox also relied on an emerging case law that was beginning to conceptualize diversity as a value in higher education. For example, in Sweatt v. Painter, ${ }^{94}$ the Supreme Court held that a university's segregation of black and white students into separate law schools violated the constitutional prohibition against excluding black students on the basis of race. ${ }^{95}$ Sweatt, represented by Thurgood Marshall and the NAACP, had been rejected from the University of Texas Law School because he was black. After some initial litigation, the university admitted him into a separate law school for black students. ${ }^{96}$ The Court felt this was as much a deprivation as excluding him outright. ${ }^{97}$ In so holding, the Court described the importance of interaction between diverse students:

The law school, the proving ground for legal learning and practice, cannot be effective in isolation from the individuals and institutions with which the law interacts.

\footnotetext{
${ }^{92}$ See Walter J. Leonard, Pioneer of Affirmative Action in Harvard Admissions, Dies at 86, N.Y. TIMES (Dec. 16, 2015), http://www.nytimes.com/2015/12/17/education/walter-j-leonard-pioneer-ofaffirmative-action-in-harvard-admissions-dies-at-86.html; Geoffrey D. Garin, Bok's Tough Bargainer in the Action Office, HARV. CRIMSON (June 13, 1974), http:/www.thecrimson.com/article/1974/6/13/boks-tough-bargainer-in-theaction.

${ }^{93}$ We have no evidence that Dean Erwin Griswold ever joined the conversation, but it would not be surprising if he had. He, too, was a former Harvard dean and was Cox's professor at Harvard; he became solicitor general three years after Cox, who recommended him for the position; he co-authored an amicus brief in Sweatt v. Painter (see infra notes 100-03 and accompanying text) that Cox cited in his brief in DeFunis; and he submitted an amicus brief in DeFunis on behalf of the American Association of Law Schools in which he also briefly made the diversity argument, citing Sweatt. See Cox Brief, supra note 1 , at $18-19$.

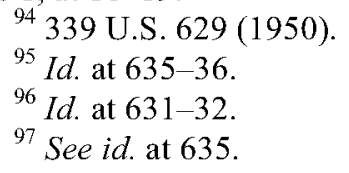


Few students and no one who has practiced law would choose to study in an academic vacuum, removed from the interplay of ideas and the exchange of views with which the law is concerned. ${ }^{98}$

This language, which Cox later quoted in his DeFunis brief, ${ }^{99}$ was likely informed in part by another former Harvard dean, Erwin Griswold. Griswold co-authored an amicus brief in Sweatt that outlined an early diversity argument. ${ }^{100}$ Not only did the Sweatt Court adopt that argument, ${ }^{101}$ but Cox's DeFunis brief also cited it directly from Griswold's brief. As Cox put it, Griswold had captured Harvard's particular understanding of the "educational importance of diversity." 102 The brief, submitted when Griswold was Dean of Harvard Law School, explained that

The lawyer ... must have a vital sense of the culture of the community in which he lives and works. . . The knowledge required ... can in part be obtained from books; but a major share must come from intimate knowledge of the ways of thought of the community. He (the lawyer) is literally lost unless he can sense the drives, interests (and weaknesses) of those with whom he deals - whether as witnesses, negotiators, judges, clients, or opponents. ${ }^{103}$

Cox also relied on another legal concept that, although familiar to us today, was also then just developing in the case law: the marketplace of ideas. The marketplace of ideas is in its essence a diversity theory. It provides that the best way to find truth is by allowing many diverse, competing ideas to be freely expressed, and allowing their intellectual persuasiveness to winnow out the wheat from the chaff.

It is a Millsian notion right out of the pages of On Liberty. ${ }^{104}$ It was first expressed in American law by Justice Holmes' famous dissenting opinion in Abrams v. U.S., ${ }^{105}$ where Holmes, describing the First Amendment's philosophical underpinnings, wrote that "the ultimate good desired is better reached by free trade in ideas - that the best test of

${ }^{98}$ Id. at 634 .

${ }^{99}$ See Cox Brief, supra note 1 , at 25.

${ }^{100}$ Brief for The Committee of Law Teachers Against Segregation in Legal Education as Amici Curiae Supporting Petitioner, Sweatt v. Painter, 339 U.S. 629 (1950), 1950 WL 78683 [hereinafter Griswold Brief].

${ }_{101}$ Compare Sweatt, 339 U.S. at 635, with Griswold Brief, supra note 100.

${ }^{102}$ Cox Brief, supra note 1 , at 18.

${ }^{103}$ Id. at 18-19 (internal quotations omitted) (quoting Griswold Brief, supra note 100$)$.

${ }^{104}$ See John StUart MiLl, On LiberTy (Michael B. Mathias ed., 2007) (1859). For more on how Mill's On Liberty influenced the development of the idea of diversity, see discussion at page 191.

${ }^{105} 250$ U.S. $616(1919)$. 
truth is the power of the thought to get itself accepted in the competition of the market". ${ }^{106}$ Where did Holmes come up with that idea? We know from his correspondence with British political theorist Harold Laski that in the months before his Abrams dissent, he re-read On Liberty and was impressed. ${ }^{107}$

The marketplace of ideas concept made its way into Cox's brief in at least two ways. First, the great Harvard Dean Charles Eliot incorporated it into the university's educational philosophy, and in so doing set the foundation for the Harvard diversity policy described in the DeFunis brief (Eliot's influence is discussed in greater detail infra at Section III).

Second, the Court had started applying the marketplace of ideas concept to educational institutions, yielding a theory of constitutionally exalted "academic freedom" that was integral to Cox's diversity justification. For example, Cox argued that "[e]ducational programs and the admissions policies and practices that affect them lie in the realm of ideas, where the highest importance attaches to academic freedom for both State and privately-endowed institutions." 108 For support, Cox cited Keyishian v. Board of Regents of the University of the State of New York, ${ }^{109}$ in which Justice Brennan declared that academic freedom is "a special concern of the First Amendment," because "[t]he classroom is peculiarly the "marketplace of ideas." "110

From the Bender and Glimp reports, the discussions at Harvard, and the developing case law on diversity and academic freedom emerged a cogent description of the Harvard admissions program as of 1974. The program Cox described relied on a long history of seeking diversity in the student body, ${ }^{111}$ transformed during the 1950's and 60's as the civil rights movement gripped the country, to include the value of making Harvard more diverse by recruiting Black and Latino students alongside rural students, athletes, legacies, artists, Westerners, Southerners, and local Cambridge/Bostonians. What did it mean for Harvard? Historian Jerome Karabel summarizes the transformation as follows:

In an atmosphere in which the claims of the excluded occupied the moral high ground, it became increasingly difficult to justify policies that favored WASPs over Jews, prep school students over high school students,

106 Id. at 630 .

107 See Irene M. Ten Cate, Speech, Truth, and Freedom: An Examination of John Stuart Mill's and Justice Oliver Wendell Holmes's Free Speech Defenses, 22 YALE J.L. \& HUMAN. 35, 38 (2010) (citing Letter from Oliver Wendell Holmes to Harold J. Laski (Feb. 28, 1919), in 1 HolmES-LASKI LETTERS: THE CORRESPONDENCE OF MR. JUSTICE Holmes AND HAROLD J. LASKi 1916-1935, at 187 (Mark DeWolfe Howe ed., 1953)).

${ }^{108}$ Cox Brief, supra note 1 , at 24.

109385 U.S. 589

${ }^{110} \mathrm{Id}$. at 603 .

111 Just how long is discussed in the next section. 
and the affluent over those who needed scholarship assistance. With the notable exception of alumni sons . . . elite constituencies that had long been given preference in the admissions process saw their privileges considerably eroded in the 1960 's. At the same time, groups that had been traditionally discriminated against - Jews, graduates of public high schools, and scholarship applicants - came to be treated in a far more even fashion. Paradoxically, then, the black struggle for inclusion - often thought to be in fundamental conflict with the logic of meritocracy - contributed to the emergence of admissions policies at Harvard, Yale, and Princeton that were far more meritocratic in 1970 than in $1960 .^{112}$

\section{THE ORIGINS OF THE DIVERSITY JUSTIFICATION FOR AFFIRMATIVE ACTION}

If the diversity justification for affirmative action was first articulated in the post-war period, it might have seemed tainted by the worst period in Harvard's history, when Harvard President Abbott Lawrence Lowell instituted a quota on the admission of Jewish students. The quota, which was put in place in $1926^{113}$ and lasted until the aftermath of World War II, was at times communicated to the outside world as a quest for regional diversity. It gave diversity a rotten name. But as ugly as the quota was, we should not make the mistake of thinking that the support for diversity in the 1950 's, 60 's, 70 's and thereafter was simply a continuation of, or smokescreen for, excluding Jews. The commitment to diversity, in its modern meaning, was an important part of Harvard's mission long before and again after the ugly days of the Jewish quota.

Harvard's greatest president, ${ }^{114}$ Charles Eliot, saw diversity as central to the educational function of the university. Eliot served as president from 1869 to 1909 , and transformed Harvard from a sleepy regional college to the world's greatest private university. From his inaugural speech to his battles with his successor Abbott Lowell over the Jewish quota, immigration, and the treatment of Black and Jewish students at Harvard, Eliot pushed the university into a broader and deeper embrace of diversity. In President Eliot's inaugural speech he described Harvard as a place for the poor as well as the rich, the sons of professional men, traders, mechanics and farmers. ${ }^{115}$ Under his leadership, Harvard had the most generous scholarships of that time. ${ }^{116}$

\footnotetext{
112 KARABEL, supra note 8, at 409.

${ }^{113} \mathrm{Id}$. at $77-109$.

${ }^{114}$ See infra pp. $188-92$.

${ }^{115}$ KARABEL, supra note 8, at 40.

${ }^{116} \mathrm{Id}$.
} 
How important was Eliot in Harvard's history? W.B. Carnochan writes of Eliot: "American higher education has never been the same after him." Jerome Karabel describes him as not only

the nation's leading college president. . . [but] Dubbed "First Citizen of the Republic" by Theodore Roosevelt (whose feelings toward him were, at best, ambivalent) . . . [He was] revered by both his peers in higher education and his fellow citizens. When he retired in 1909 after forty years of service, he had succeeded not only in transforming Harvard, but in changing the definition of a great university. No college president, before or since, has exerted a greater impact on the shape and character of American higher education. ${ }^{118}$

Some of Eliot's principal reforms and accomplishments included: refocusing the College's curriculum away from religious topics and toward the physical and social sciences; allowing undergraduates to choose their own course of study; creating and/or transforming the professional and graduate schools in the areas of medicine, law, the arts, and sciences; revitalizing the campus buildings; and the creation of Radcliffe College. ${ }^{119}$ As his biographer Henry James (nephew of the great American novelist of the same name) wrote in his Pulitzer Prize winning biography, Eliot "preach[ed] the necessity of widening the scope, deepening the work, and liberalizing the spirit of the American colleges." 120 That liberalization included a commitment to diversifying the faculty and student body of Harvard College.

In September 1900, in an inaugural speech welcoming the incoming class of 1904, which included future President Franklin D. Roosevelt, Eliot again took up the question of socio-economic diversity, terming it a common error to believe that Harvard was only a place for the rich, and promising the incoming students that they would learn much from each other because they came from many different backgrounds. Karabel reports that over $40 \%$ of that class came from public schools, and that the single largest "feeder" school that year was Boston Latin, a public school. $^{121}$

Former Harvard President Neil Rudenstine reports that prior to Eliot being named President, there had been no Black graduates from Harvard

${ }^{117}$ W.B. CARNOCHAN, THE BATtLEgRoUnd of THE CURRICUlum: LibERAL

EDUCATION AND AMERICAN EXPERIENCE 2 (1993).

${ }_{118}^{11}$ KARABEL, supra note 8 , at 39.

119 Henry James, Charles W. Eliot: President of Harvard UNIVERSITY, 1869-1909, at 67 (1930).

${ }^{120}$ Id. at 221.

${ }^{121}$ KARABEL, supra note 8, at 13. 
College. ${ }^{122}$ Eliot welcomed them, if in small numbers. ${ }^{123}$ And even small numbers had an impact on another kind of diversity. Historian Samuel Eliot Morison reports that "Southerners avoided Harvard after the Civil War because it admitted Negroes on the same terms as whites, allowing them to eat at Memorial Hall, room in college dormitories, and participate in debating and athletic contests." ${ }^{24}$ As discussed below, that would change for a time after Eliot stepped down.

As President Eliot was preparing to step down after 40 years at the helm, Harvard was becoming increasingly diverse. Jerome Karabel reports that in 1908 Harvard College had 29 Black students and 60 foreigners, and that

By the standards of the Big Three, Harvard was remarkably heterogeneous under Eliot; in 1908, his last full year in office, public school students constituted 45 percent of the freshman class, and one student in six was either Catholic $(9 \%)$ or Jewish (7[\%]). A further sign of Harvard's cosmopolitanism was its openness to blacks, immigrants, and foreigners. A homogeneous New England college when Eliot studied there in the 1850's, Harvard had by the early 1900 's become genuinely diverse, a place where the 'collision of views' that Eliot valued so highly was powerfully reinforced by the sheer variety of students. ${ }^{125}$

Lest one think that Karabel was misusing the term "diversity" to describe Harvard in contemporary terms, Eliot too was using it in its contemporary meaning. In a speech made in March 1911, reported in the New York Times, Eliot is quoted as stating "I cannot imagine greater diversity than there is in Harvard College. It is not superficial; it is deep. It is shown in the variety of races, religions, households from richest to poorest, and in the mental gifts and ambitions." 126

${ }^{122}$ There were a few black students in the professional schools when Eliot arrived. The first four Black students graduated from Harvard Medical School, Harvard Law School, and the Harvard School of Dental Medicine in 1869. See Chronology of Major Landmarks in the Progress of African Americans in Higher Education, THE JOURNAL OF BLACKS IN HigheR EDUCATION (2006), http://www.jbhe.com/features/53 blackhistory_timeline.html.

${ }^{123}$ NeIL L. Rudenstine, Diversity and Learning at Harvard: A Historical View, in POINTING OUR THOUghts: ReFlections ON HARVARD AND Higher EDUCATION 24-25 (2001) (It was Rudenstine who first made the link between John Stuart Mill, Charles Eliot, and diversity.).

${ }^{124}$ SAMuel Eliot Morison, Three Centuries of Harvard: 1636-1936, at 416-17 (1965).

${ }^{125}$ KARABEL, supra note 8, at 45.

${ }^{126}$ NO EQUALITY IN OUR INSTITUTIONS--ELIOT; Tells Harvard Students Uniform Conditions Are Only Possible Under a Despotism, N.Y. TIMES (Mar. 
From what source did President Eliot develop his ideas about the value of diversity? Former Harvard President Neil Rudenstine argues that Eliot was following the lead of the great political theorist and activist John Stuart Mill. ${ }^{127}$ In Mill's seminal work, On Liberty, his argument in favor of liberty is punctuated with frequent references to the value of diversity. ${ }^{128}$ Mill was primarily concerned with the value of insuring that in any debate there were people with diverse points of view, developed from diverse backgrounds and experiences. ${ }^{129}$ Although Mill, like Eliot, was an abolitionist and strong believer in equal rights and an equal voice for women and minorities, he did not directly link his advocacy for diversity to race, religion or ethnicity. But he did link it to class, background and experience. ${ }^{130}$ It was easy for Eliot, well versed in Mill's writings on diversity, to take that next step. Should we then view John Stuart Mill as the parent of affirmative action? We certainly can. And we can do so based not only on his embrace of the importance of diversity in On Liberty, but also on his role in popularizing the idea of proportional representation, to which he was also deeply committed. ${ }^{131}$

How do we know that Eliot was familiar with Mill's work? Eliot was a great believer in what we today call the "Great Books" approach to education (or self-education). He asserted that the basis of a liberal education could be collected in a five-foot shelf of great books. When he stepped down from the Harvard presidency in 1909 the publisher P.F. Collier and Son invited him to collect and edit his five-foot shelf of books, now known as the "Harvard Classics." Among the books he selected was Mill's On Liberty. Moreover, Eliot's biographer Henry James tells us that Eliot quoted Mill in an 1873 report to the National Education Association. ${ }^{132}$ Tying Eliot's belief in the value of diversity of opinion to the views of Mill, James wrote, "The exemplary generosity with which Eliot accommodated himself and his work to opposition and disagreement showed how genuinely he believed what John Stuart Mill, Herbert Spencer and his own Unitarians preached." 133

In sum, the roots of Harvard's diversity policies described in the Cox brief are deep, reaching back to the leadership of President Eliot and his

http:/query.nytimes.com/gst/abstract.html?res=9A05EEDB143EE033A25752C 2A9659C946096D6CF (Eliot goes on to describe views odious to us today, including his opposition to "racial mixing" as forming "an inferior breed.").

${ }^{127}$ RUDENSTINE, supra note 123, at 19, 23.

${ }^{128}$ See generally MILL, supra note 104 (extolling the importance of diversity fifteen times).

${ }^{129} \mathrm{Id}$.

${ }^{130}$ Id. at $10-12,21-25,54,63,117$.

131 See John Stuart Mill, Representative Government Chapter VII (1861).

1321 Henry James, Charles W. Eliot: President of Harvard UNIVERSITY 1869-1909, 326-27 (1930).

${ }^{133}$ Id. at $348,371$. 
vision of Harvard as a place where all kinds of diversity, including racial, ethnic and religious diversity, were to be celebrated and nurtured. But then came Eliot's successor, President Abbott Lowell, and the Jewish quota that stained Harvard's reputation as a place of openness and fairness.

Abbott Lowell was not Charles Eliot's preferred candidate to succeed him as president. Eliot hoped that either Board member Jerome Greene or Boston lawyer Louis Brandeis would be appointed. Regarding Brandeis, Eliot had commented, "I am a Unitarian. It would please me to be followed by a Jew." "134 In a warning of what would soon come, the Harvard Corporation passed over Greene and Brandeis, selecting Lowell. When Brandeis was appointed to the Supreme Court a few years later, with the near-unanimous support of the Harvard Law faculty, Lowell and Eliot squared off again. Lowell helped lead a campaign against Brandeis widely understood to be anti-Semitic, ${ }^{135}$ while Eliot was a vocal supporter of Brandeis. ${ }^{136}$

At the time of Lowell's selection, he and Eliot had clashed for over a decade on the major public policy issue of the late nineteenth and early twentieth centuries - immigration. Lowell was active in the Immigrant Restriction League, founded in 1894. In 1912, soon after his selection as Harvard's President, he was named vice president of the League. ${ }^{137}$ Lowell believed in the superiority of Anglo-Saxon values and customs; he claimed that immigrants from Eastern and Southern Europe (mostly Russian and Polish Jews and Polish and Italian Catholics) would dilute the stock of the white race. ${ }^{138}$ Eliot, on the other hand, believed that immigrants had made America great. "We need them," he wrote, "whether they are Jews or Gentiles, Greeks or Barbarians, literate or illiterate, skilled or unskilled, children or adults." ${ }^{\prime 139}$ Karabel reports that by 1921 Eliot had embraced the emerging theory of cultural pluralism, writing that the United States "would benefit from being 'a country of many races, many religions, and many varieties of human nature, forming one liberty-loving stable democracy." ${ }^{140}$

${ }^{134}$ Oliver B. Pollak, Antisemitism, the Harvard Plan, and the Roots of Reverse Discrimination, 45 JEWISH SOC. STUD. 113 (1983) (citing ALlON GAL, BRANDEIS OF BOSTON 154 (1980)); Reveal President of Harvard Favored Brandeis as Successor, JEWISH DAILY BULl., Dec. 14, 1930, http://pdfs.jta.org/1930/1930-12-14_1833.pdf.

135 David G. Dalin, Jewish Justices of the Supreme Court, 47-48 (2017).

${ }^{136} \mathrm{Id}$.

${ }^{137}$ KARABEL, supra note 8 , at $47-48$.

${ }^{138}$ Id. at 48.

${ }^{139}$ Id. (citing Marcia G. Synnott, A Social History of Admissions Policies at Harvard, Yale, and Princeton, 1900-1930, at 210 (1974)).

${ }^{140}$ KARABEL, supra note 8 , at 49. 
At Harvard, Eliot had liberalized the University in ways that offended Lowell. He ended the requirement that students attend chapel, and though he himself was a Unitarian, he had brought in chaplains who were not Unitarians and even permitted a Catholic priest to lead a service at the Harvard chapel. ${ }^{141}$ Moreover, Lowell opposed Eliot's curricular reforms, including his decision to abandon a required course of study in favor of electives, and was supported by educational conservatives. ${ }^{142} \mathrm{He}$ sought to distance Harvard from Radcliffe, which Eliot had helped found. ${ }^{143}$ In Lowell's view, the right students for Harvard would be those who were already part of the social elite. ${ }^{144}$

When Lowell took office, he ordered that Black students no longer be permitted to live in the freshman dorms or eat in the dining halls. ${ }^{145}$ The issue lay quietly for a while, but when a Black student publicized his exclusion from the freshman dorms in 1922, Eliot, as President Emeritus, and still an important figure, sided with the student. ${ }^{146}$ So did many of Harvard's white students and alumni, ${ }^{147}$ whose protests ultimately forced Lowell to back down, but not before the issue played out in the national press. ${ }^{148}$ NAACP President (and Harvard Ph.D.) W.E.B. Du Bois linked Lowell to the then-resurgent Ku Klux Klan, ${ }^{149}$ which Lowell had refused to condemn. ${ }^{150}$ In turn, the Klan condemned Eliot. ${ }^{151}$

141 See Eliot, Charles W. (1834-1926), Harv. SQUARE LiBr., http:/www.harvardsquarelibrary.org/biographies/charles-w-eliot-harvarduniversity-president.

${ }^{142}$ KARABEL, supra note 8, at 45 (describing Lowell as at "the head of the forces opposing Eliot," and noting that Lowell "sharply criticized the elective system.").

${ }^{143}$ Morton Keller \& Phyllis Keller, Making Harvard Modern: The RISE OF AMERICA'S UNIVERSITY 52 (2001).

${ }^{144}$ Id. at 32.

${ }^{145}$ KELLER, supra note 143, at 60; see also Nell Painter, Jim Crow at Harvard: 1923, 44 NEW ENG. Q. 627 (1971); WILliaM WRIGHT, HARVARD'S Secret Court: The Savage 1920 Purge of Campus Homosexuals 64 (2005).

${ }^{146}$ See Karabel, supra note 8, at 101 (noting that Harvard's decision in 1923 to end Lowell's policy of excluding African Americans from the freshmen dormitories was "[t]o Eliot's great satisfaction.").

${ }^{147}$ Puttkammer, supra note 71 , at 14.

${ }^{148}$ Painter, supra note 145 , at 628 .

${ }^{149}$ In the 1920 's, membership in the Ku Klux Klan reached its zenith at the four million mark, at a time when the entire U.S. population was only a little over one hundred million people. Theofore Rosengarten, The Brotherhood of the Shroud, N.Y. TIMES (Apr. 26, http://www.nytimes.com/1987/04/26/books/the-brotherhood-of-theshroud.html?pagewanted=all.

${ }^{150}$ Painter, supra note 145 , at 630 (citing W.E.B. Du Bois, xxiv CRISIS 153 (1922)). An equal opportunity racist, Lowell also recommended that Harvard not condemn Hitler. KELLER, supra note 143, at 154. 
The biggest clash between Eliot and Lowell would be over the Jewish quota. Lowell's view of Jews, and fear of their presence at Harvard, is aptly summed up by a letter he wrote, uncovered by Karabel, in which he stated, "The summer hotel that is ruined by admitting Jews meets its fate, not because the Jews it admits are of bad character, but because they drive away the Gentiles, and then after the Gentiles have left, they leave also." $" 152$

As Jewish immigration rose in the early twentieth century, so did the enrollment of Jewish students at Harvard and other elite colleges. By 1918 , Harvard's freshman class was $20 \%$ Jewish ${ }^{153}$ By 1922, with the proportion of Jewish students at Harvard at $21.5 \%$, Lowell moved decisively. ${ }^{154}$ His first step was to instruct the admissions committee to limit the numbers of Jews accepted. But Professor Henry Pennypacker, the committee chair, refused without a clear policy adopted by the faculty. ${ }^{155}$ Lowell then arranged to propose to the faculty a $15 \%$ Jewish quota. The faculty refused to adopt a numerical quota, but gave Lowell a partial victory by passing a resolution instructing the admissions committee to take racial and national origin into account in its decision-making. ${ }^{156}$

Following objections from the public and members of Harvard's Board of Overseers, plus second thoughts by members of the faculty, Lowell was forced to return to the full faculty for another vote. There, the earlier vote was rescinded, and a proposal to impose a quota failed. The faculty agreed, however, to the appointment of a special committee to study the matter. ${ }^{157}$ Charles Eliot, though by now in his late eighties, had one more fight left in him. He joined with a few influential faculty and Board members to lobby the committee. The public, the press, Harvard's students, and many Harvard alumni joined him in his opposition to Lowell's proposed quota. After a year of study, the committee released its report, unanimously recommending no change in Harvard's admission policies, ${ }^{158}$ and affirming Harvard's commitment to "the policy of equal opportunity for all regardless of race or religion.," 159

But Lowell wasn't done. The committee had approved measures to admit more students from the South and West, which Eliot and his allies worried would be used as a subterfuge to exclude Jewish applicants,

${ }^{151}$ Hiram Wesley Evans, The Klan's Fight for Americanism, N. AM. REV. 33, 60-61 (1926) (Hiram Wesley Evans was the Imperial Wizard and Emperor, Knights of the Ku Klux Klan).

${ }^{152}$ KARABEL, supra note 8 , at 88 .

${ }^{153} \mathrm{Id}$. at 86.

${ }^{154} I d$. at 89.

${ }^{155}$ Id. at 90 .

${ }^{156} \mathrm{Id}$.

${ }^{157}$ Id. at $91-93$.

${ }^{158}$ KARABEL, supra note 8, at 93-100.

${ }^{159}$ Id. at 101. 
most of whom resided in large Eastern cities. ${ }^{160}$ And a further committee on class size recommended, to Lowell's delight and Eliot's consternation, that the freshman class be limited to 1,000 students, thus requiring more subjective decisions by the admissions committee as it increased its selectivity. When that committee's report went to the Board of Overseers in January of 1926, the Board sided with Lowell. A few days later, the faculty further agreed that the admissions committee should gather information about applicants' character and fitness. ${ }^{161}$ Lowell had won. The admissions committee now had approval to limit the class size, consider applicants through a subjective test of character, and provide a preference for geographic diversity. In the fall of 1926, without announcing it publicly, the Harvard admissions committee adopted a Jewish quota of $15 \%$. ${ }^{162}$

The Jewish quota adopted in 1926 was described, in part, as a commitment to regional diversity. By justifying the quota through the use of the term "diversity," Lowell was reaching back to and polluting Harvard's long tradition of admitting students of all races and religions and encouraging students to learn from each other's differences. But that long tradition remained part of Harvard's history, and would begin to be restored in the 1950's and thereafter, under the leadership of deans Monro, Glimp and Bender.

Did Harvard's commitment to diversity begin with Charles Eliot? No. Even before President Eliot began putting John Stuart Mill's ideas about diversity to work, the value of diversity (if not the term) was seen as a part of Harvard's mission. In 1860, Harvard President Cornelius Felton reported to the Board that he was seeking students from every state, in part in the hope that in studying together they would learn from each other's different experiences, and in the process reduce the risk of civil war. $^{163}$

And even before Felton became president in 1860, Harvard was recruiting students from the South to increase its diversity. ${ }^{164}$ Henry Adams, in the great American autobiography, The Education of Henry Adams, writes of how his views were broadened in his four years as a student at Harvard College (1854-58) by the addition of three Virginians to his class of nearly one hundred young men from New England. One was the son of the American general (and future Confederate General) Robert E. Lee. Adams writes that for the first time his

education brought him in contact with new types and taught him their values. He saw the New England type measure itself with another, and he was part of the pro-

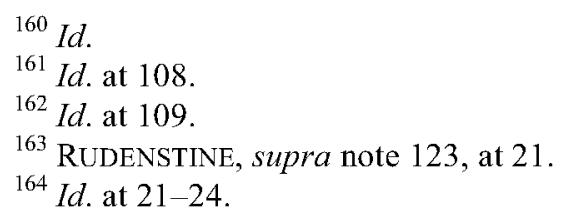


cess ... At a moment when the immediate future posed no problem in education so vital as the relative energy and endurance of North and South, this momentary contact with Southern character was a sort of education for its own sake. ${ }^{165}$

But it was Charles Eliot who, in re-making Harvard into a great university, put John Stuart Mill's ideas on diversity to work, helping to set Harvard on the path to the diversity policies adopted by every selective U.S. college today.

\section{COX, HARVARD, AND AFFIRMATIVE ACTION AFTER DEFUNIS.}

After completing the amicus brief in DeFunis, Archibald Cox spent a semester on sabbatical in London, and then returned to Harvard and resumed his teaching schedule. ${ }^{166}$ Three years later, when the Bakke case was accepted for review, the petitioner, the University of California, asked Cox to represent them at oral argument in the Supreme Court. In his argument, he presented the University of California's position that the California Supreme Court had erred, that the Civil Rights Act and the Constitution did not prohibit public universities from considering race in admitting students, and that there were several good reasons to permit the university to do so. But although the UC Davis brief had included a section on the diversity justification for affirmative action and the amicus brief for the four elite colleges had framed the diversity argument as Cox had developed it in the DeFunis case, it was not raised at oral argument, either by Cox or through the Justices' questions. ${ }^{167}$

When the Bakke decision was released, most legal commentators initially failed to appreciate the significance of the diversity justification. The early reaction was that Justice Powell had found a middle ground by prohibiting quotas while endorsing the use of race as a plus factor. But the importance of using it as a plus factor for the purpose of pursuing a mission of student diversity was not widely appreciated.

For example, in Joel Dreyfuss and Charles Lawrence's 1979 book, The Bakke Case: The Politics of Inequality, ${ }^{168}$ the index contains no reference for diversity. In over 250 pages of text, the Harvard approach to

165 Henry ADAMS, THE EDUCATION OF HENRY ADAMS: AN Autobiography 57-58 (1918). Discussed in RudEnSTINE, supra note 123, at $21-23$.

166 Ken Gormley, Archibald Cox: Conscience of a Nation 393-94 (1997).

${ }^{167}$ We know from Justice Powell's archives that one of the questions he intended to ask Cox was how Harvard went about choosing an Idaho farm boy over a Boston first-family son, and whether there was a guarantee of a certain number of seats for farm boys. But he didn't get to the question before time ran out. See Justice Powell's Bakke archives, supra note 37, at folder 4.

168 Joel Dreyfuss \& Charles Lawrence III, The Bakke Case: The POLITICS OF INEQUALITY 269-73 (1979). 
diversity gets all of five paragraphs. ${ }^{169}$ Justice Powell's opinion is described as a compromise, ${ }^{170}$ but its embrace of diversity is barely mentioned, and the appendix to Justice Powell's opinion describing the Harvard approach is not mentioned at all.

Bernard Schwartz, in his in-depth examination of the decision ten years after it was issued, ${ }^{171}$ discusses the diversity justification only briefly. In his view, the importance of the decision is the holding that colleges and universities may take account of race as long as there is no quota or numerical goal; he treats the goal of diversity as merely a means to an end -- providing preferences to minority students. Thus, he writes, "[t]hough the Davis program was invalidated, the Powell opinion permits admissions officers to operate programs which grant racial preferences - provided that they do not do so as blatantly as was done under the sixteen-seat 'quota' provided in Davis... The result has been that Bakke has, in practice, served to license, not to prohibit, race-conscious admissions programs." "172

Similarly, in political scientist Howard Ball's 2000 book, The Bakke Case: Race, Education and Affirmative Action, there is no discussion at all of diversity as a justification for affirmative action. He describes Justice Powell's opinion as a compromise that permits considerations of race, but does not describe the underlying diversity rationale. ${ }^{173}$

For one last example, in John C. Jeffries, Jr.'s 1994 biography of Justice Powell, ${ }^{174}$ the word "diversity" does not appear in the index. ${ }^{175}$ Recall that it was Jeffries, as Powell's law clerk, who in 1974 recommended that Powell read the Cox brief in the DeFunis case. ${ }^{176}$ But in his biography his discussion of how Justice Powell came to embrace the diversity justification takes all of five pages out of 562, and describes it as a "middle ground" rather than a different conception of affirmative action, ${ }^{177}$ as we now think of it. In Jeffries' view, writing sixteen years after the Bakke decision, the difference between the Harvard program to foster diversity, including racial diversity, and the Davis program to counteract racial disadvantage and train minority physicians was "more form than substance."178 "Harvard," Jeffries' writes, "was simply Davis without

${ }^{169}$ Id. at $126-27,211-12$.

${ }^{170} \mathrm{Id}$. at $211-12$.

${ }^{171}$ SCHWARTZ, supra note 5 , at $151-56$.

${ }^{172} I d$. at $153-54$.

173 Howard Ball, The Bakke Case: Race, Education, AND AFFIRMATIVE ACTION 122-33 (2000).

174 John C. Jeffries, JR., Justice Lewis F. Powell, JR.: A Biography (1994).

${ }^{175} \mathrm{Id}$. at 680 .

${ }^{176}$ See Memorandum from John C. Jeffries, Jr. to Justice Powell, supra note 34.

177 JEFFRIES, supra note 174 , at 475-78, 484-85.

${ }^{178}$ Id. at 484 . 
fixed numbers." ${ }^{179}$ He concludes that for Justice Powell, "diversity was not the ultimate objective but merely a convenient way to broach a compromise." 180

As Professor Jeffries has more recently reported, at the time of the decision " $[\mathrm{r}]$ eviews of the intellectual craft of Powell's opinion were largely negative and sometimes scathing." ${ }^{181}$ Jeffries quotes from articles by eight leading legal scholars from left to right, all of whom, writing in 1978 or ' 79 , agreed that the opinion was seriously problematic. ${ }^{182}$ Each treated the opinion as an attempted compromise, but none focused on the diversity rationale as integral to the opinion.

But the tide turned.

When Justice Powell stepped down from the Court in 1987, nine years after the Bakke decision, he was asked which was his most important opinion. Without hesitation, he replied, the Bakke opinion, and specifically mentioned that 63 amicus briefs were submitted in the case. ${ }^{183}$ The New York Times ran a sidebar with excerpts from Justice Powell's major opinions, beginning with Bakke. Of the three paragraphs from the case, one was the portion where he summed up his support for permitting a university to make its own judgments about the selection of its student body, and to seek a diverse student body. ${ }^{184}$

Cox's 1997 biography, by Duquesne law professor and University President Ken Gormley, similarly recognizes the importance of the diversity justification and Cox's central role as counsel to the University of California in the Bakke case, though it fails to link his brief in DeFunis to the outcome of Bakke. ${ }^{185}$

Of course, Archibald Cox understood the centrality of diversity to the Bakke decision. In July of 1979 the Rockefeller Foundation brought together a group of leading civil rights lawyers and legal scholars for a two-day discussion ${ }^{186}$ of the Bakke case and the Weber case. ${ }^{187}$ Cox contributed a paper, titled "Minority Admissions After Bakke." ${ }^{188}$ In his pa-

${ }^{179} \mathrm{Id}$.

${ }^{180} \mathrm{Id}$. at 500

${ }^{181}$ John C. Jeffries Jr., Bakke Revisited, 2003 SUP. CT. REV. 1, 9 (2003).

${ }^{182} I d$. (citing articles by Guido Calabresi, Vincent Blasi, Harry T. Edwards, Ronald Dworkin, John Hart Ely, Laurence H. Tribe, Robert H. Bork, and Antonin Scalia).

${ }^{183}$ SCHWARTZ, supra note 5, at 1 (citing Linda Greenhouse, Powell: Moderation Amid Divisions, N.Y. TIMES, June 27, 1987).

184 Linda Greenhouse, Powell: Moderation Amid Divisions, N.Y. TIMES (June 27, 1987), http://www.nytimes.com/1987/06/27/us/powell-moderationamid-divisions.html.

${ }^{185}$ Gormley, supra note 166 , at 401-06.

${ }^{186}$ See Bakke, Weber, and Affirmative Action: A Rockefeller Foundation Conference (The Rockefeller Foundation, Working Paper, 1979).

${ }^{187}$ United Steelworkers of Am., AFL-CIO-CLC v. Weber, 443 U.S. 193 (1979).

${ }^{188}$ Bakke, Weber, and Affirmative Action, supra note 186 , at 80-112. 
per, Cox explained that colleges could be confident that admissions programs like Harvard's would withstand legal attacks as long as they (1) emphasized diversity of all sorts, not just racial or ethnic diversity, (2) thoughtfully considered and articulated the educational value of racial and/or ethnic diversity to the general student body, (3) avoided fixed targets or quotas, and (4) evaluated applicants on a case-by-case basis, with minority status a plus, but with no one barred from consideration based on race. ${ }^{189}$ This is as close as a lawyer could hope to get to the Court's subsequent decisions in Grutter, Gratz, and Fisher, as the Court has affirmed the argument of the Cox brief in DeFunis, as set forth by Justice Powell in Bakke.

And Cox's old friend, former Harvard President Derek Bok, also saw it. His 1998 book with former Princeton President William Bowen, The Shape of the River: Long Term Consequences of Considering Race in College and University Admissions, cogently lays out the case for diversity-based affirmative action. Bowen and Bok describe Justice Powell's controlling decision in Bakke as permitting race-conscious admissions "to secure the educational benefits of a student body of diverse backgrounds and experience." 190

But it was not until 2003, twenty-five years after Bakke, that the diversity justification truly became part of the fabric of how we talk about affirmative action. In Grutter v. Bollinger ${ }^{191}$ the Supreme Court, by a 5-4 vote, re-affirmed the Powell opinion in Bakke. Justice O'Connor's majority opinion re-visited the value of diversity in higher education ("a mix of students with varying backgrounds and experiences who will respect and learn from each other"), ${ }^{192}$ and agreed that it supplies a compelling interest that justifies the use of race.

In her Grutter opinion Justice O'Connor returned to a question raised by Cox in his DeFunis brief and adopted by Justice Powell in Bakke: how much attention, if any, should colleges and universities pay to the number of minority students admitted? Recall that Cox addressed this as follows:

Comparably, 10 or 20 black students could not begin to bring to their classmates and to each other the variety of points of view, backgrounds and experiences of blacks in the United States. Their small numbers might also create a sense of isolation among the black students themselves and thus make it more difficult for them to develop and achieve their potential. Consequently, when making its decisions, the Committee on Admissions is aware that there is some relationship between numbers

\footnotetext{
${ }^{189}$ Id. at 102.

${ }^{190}$ William G. Bowen ET AL., THE SHAPE OF THE RIVER 8 (1998).

${ }^{191}$ Grutter v. Bollinger, 539 U.S. 306 (2003).

${ }^{192} I d$. at 314.
} 
and achieving the benefits to be derived from a diverse student body, and between numbers and providing a reasonable environment for those students admitted. ${ }^{193}$

Justice O'Connor, adopting the University of Michigan's terminology, described this as the "critical mass" problem. She approved of the law school's close attention to how many minority students they were admitting, agreeing with Justice Powell (and hence with Cox) that attention to numbers is important to avoid the problem of racial isolation, and to ensure that there is meaningful diversity in each year's incoming class. ${ }^{194}$

In discussing the value of diversity, Justice O'Connor, like Justice Powell, relied on amicus curiae briefs. In this instance, as recognition of the importance of diversity in American life had grown, it was the voices of business and the military that proved influential.

These benefits are not theoretical but real, as major American businesses have made clear that the skills needed in today's increasingly global marketplace can only be developed through exposure to widely diverse people, cultures, ideas, and viewpoints. Brief for $3 \mathrm{M}$ et al. as Amici Curiae 5; Brief for General Motors Corp. as Amicus Curiae 3.4. What is more, high-ranking retired officers and civilian leaders of the United States military assert that, [b]ased on [their] decades of experience, a highly qualified, racially diverse officer corps ... is essential to the military's ability to fulfill its principle mission to provide national security. Brief for Julius W. Becton, Jr. et al. as Amici Curiae 27.

Among the many amici briefs filed, a Harvard brief by a Harvard Law professor contributed once again to the discussion on the importance of diversity. The brief, submitted on behalf of Harvard, Brown, Chicago, Dartmouth, Duke, Penn, Princeton, and Yale, merged the arguments of business and military leaders with those of leading educators. Fittingly, Harvard Law School's next generation's great constitutional law scholar, Laurence Tribe, was counsel of record on the brief. And once more, Harvard's unique history of embracing diversity was before the Court. Tribe wrote:

Amici's experience during the quarter century since Bakke has confirmed the wisdom of that decision. Amici's admissions policies have served compelling pedagogical interests by contributing to a diverse and inclusive educational experience, teaching students to view issues from multiple perspectives, and helping to break 
down prejudices and stereotypical assumptions. The policies prepare students to work productively in a multiracial environment after they graduate, and the policies meet the demands of business and the professions by preparing a generation of public and private leaders for an increasingly pluralistic national and global economy. 195

In the wake of the Grutter decision, Professor Jeffries revisited his earlier views about Justice Powell's Bakke opinion and the intellectual heft of the diversity justification. Recall that in 1994 Professor Jeffries described the Harvard plan as "Davis without fixed numbers." 196 In his 2003 article, "Bakke Revisited," 197 he traced the Powell opinion's critical role in influencing how we think about diversity and affirmative action, recognizing the opinion's "wisdom." Of his own views, he explained that he has been won over by the diversity argument, ${ }^{198}$ concluding that Justice Powell "was exactly right.",199

Most recently, in Fisher v. University of Texas (Fisher II) the Court once again re-affirmed the Powell opinion in Bakke and the O'Connor opinion in Grutter, yet again finding that diversity was a proper justification for race-conscious affirmative action in higher education, and that schools could properly seek a critical mass of minority students. ${ }^{200}$ In writing for the majority, Justice Kennedy held that a university may defer to "student body diversity" as a characteristic "central to its identity and educational mission." ${ }^{201}$ The compelling interest that justifies affirmative action programs in universities, he explained, "is not an interest in enrolling a certain number of minority students. Rather, a university may institute a race-conscious admissions program as a means of obtaining 'the educational benefits that flow from student body diversity." "202 And, in turn, the Fifth Circuit in its 2014 Fisher II decision affirmed by Justice Kennedy's decision, acknowledged Justice Powell's embrace of the Harvard Plan in Bakke and described the kind of student qualities that would constitute a diverse student body, including, along with race and ethnicity, "exceptional personal talents, unique work or service experience, leadership potential, maturity, demonstrated compassion, a history of overcoming disadvantage, ability to communicate with

195 Brief for Harvard University et al. as Amici Curiae Supporting Respondents at 2, Grutter v. Bollinger, 539 U.S. 306 (2003) (Nos. 02-241, 02-516).

196 JEFFRIES, supra note 174 , at 484.

${ }^{197}$ Jeffries, supra note181.

${ }^{198} I d$. at 20.

${ }^{199}$ Id. at 19.

${ }^{200}$ Fisher v. University of Texas (Fisher II), 136 S. Ct. 2198 (2016).

${ }^{201} I d$. at 2214.

${ }^{202}$ Id. at 2203 . 
the poor, or other qualifications deemed important." ${ }^{203}$ President Obama was among many who hailed the decision. "I'm pleased that the Supreme Court upheld the basic notion that diversity is an important value in our society," he told reporters at the White House. "We are not a country that guarantees equal outcomes, but we do strive to provide an equal shot to everybody.",204

\section{CONCLUSION}

Judicial recognition of the value of diversity in higher education is relatively new, dating to Justice Powell's opinion in Bakke in 1978. But as this article makes clear, educators have valued diversity, including racial and ethnic diversity, for many years. The roots of the diversity justification for affirmative action reach back to the mid-nineteenth century and the works of John Stuart Mill and Charles Eliot. By the end of the nineteenth century, Harvard was far more open to Jewish, Catholic, Black, and foreign students than most elite American colleges, and sought them for the diversity they brought to the life of the college. While diversity was used as a cover for the appalling Jewish quota of the 1920 's and 30's, we should not let this brief (if exceedingly ugly) period stain the important contribution Harvard's commitment to diversity provided in the years before and after the quota years.

The importance of diversity to Harvard's mission, and thus its broadening role in American life and law, might well have been lost to history but for the brilliant brief prepared by one of America's great lawyers, Archibald Cox. His brief in the DeFunis case investigated, revealed, and articulated how Harvard's long history of valuing diversity justified Harvard's use of race in making admissions decisions. That description was appended to the brief filed four years later by Harvard, Columbia, Penn and Stanford as amici in the Bakke case, and was then appended to the Bakke decision itself by Justice Powell. It was such a persuasive explanation of how race can be properly considered in college admissions without violating the principles of equality that it remains the blueprint for virtually every highly selective college in America today.

The Supreme Court, in the Grutter and Fisher cases, has now twice reaffirmed the Harvard approach as articulated by Cox. Justice Ginsburg has announced that the issue is now settled, and is not likely to be revisited for many years. ${ }^{205}$ Its affirmance must be credited in part to Har-

${ }^{203}$ Fisher v. University of Texas at Austin (Fisher I), 758 F.3d 633, 643 (5th Cir. 2014), aff'd 136 S. Ct. 2198, 195 L. Ed. 2d 511 (2016).

${ }^{204}$ Adam Liptak, Supreme Court Upholds Affirmative Action Program at University of Texas, N.Y. TIMES (June 23 2016), https://www.nytimes.com/2016/06/24/us/politics/supreme-court-affirmativeaction-university-of-texas.html?_r=0.

${ }^{205}$ Adam Liptak, Ruth Bader Ginsburg, No Fan of Donald Trump, Critiques

Latest Term, N.Y. TIMES (July 10, 2016),


[Vol. 25:2

vard's continuing advocacy for diversity-based affirmative action. The commitments to minority admissions by Harvard College deans John Monro, William Bender, and Fred Glimp, by Derek Bok both as dean of the Law School and then president of the University, by Walter J. Leonard (again, both at the Law School and the University), and the scholarly work and Supreme Court advocacy of Laurence Tribe, are a few examples among many. But history should not forget the contribution of Archibald Cox, and his nearly lost brief in the DeFunis case.

https://www.nytimes.com/2016/07/11/us/politics/ruth-bader-ginsburg-no-fan-ofdonald-trump-critiques-latest-term.html?_r=0. 